UCRL-ID-122860

\title{
Electrochemical Corrosion Studies of Container Materials in Repository-Relevant Environments
}

Cutar and

A. K. Roy

G. A. Henshall

R. D. McCright
FE8 20 1340

OSTI

\section{December 12, 1995}

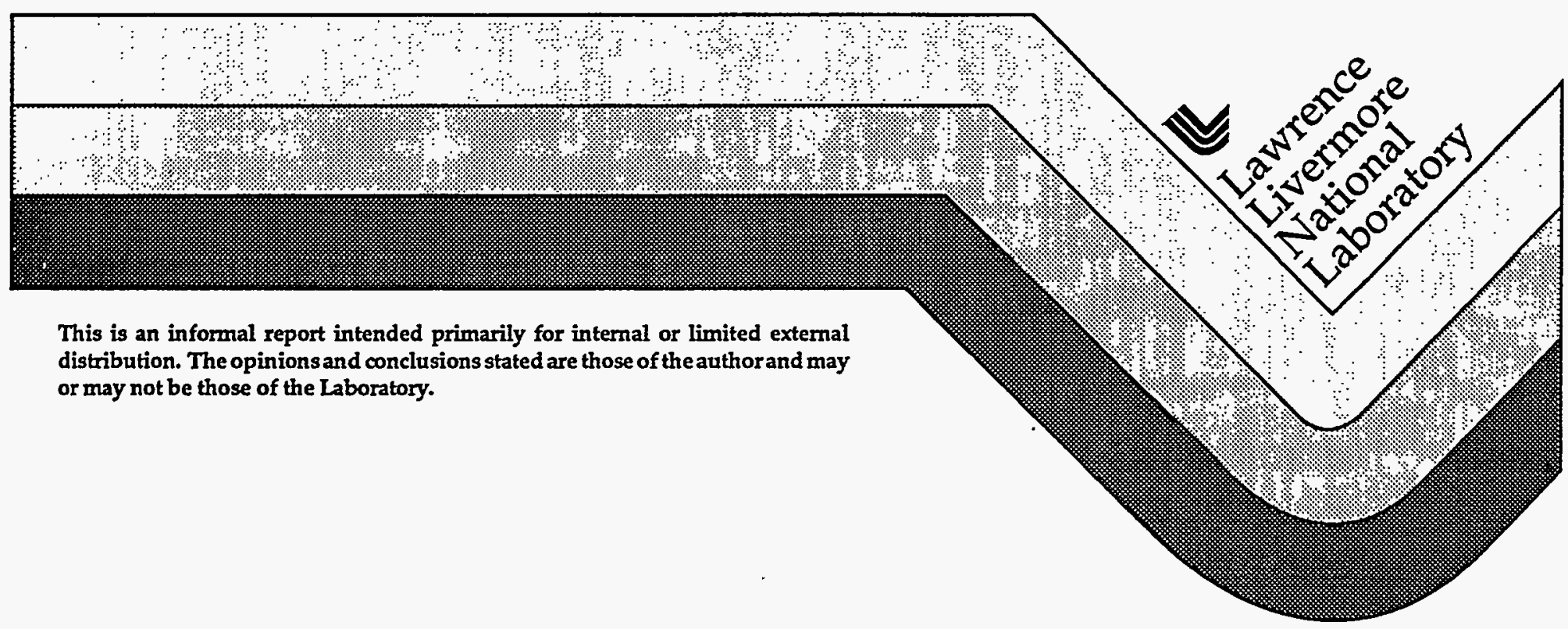




\section{DISCLAIMER}

This document was prepared as an account of work sponsored by an agency of the United States Government. Neither the United States Government nor the University of California nor any of their employees, makes any warranty, express or implied, or assumes any legal liability or responsibility for the accuracy, completeness, or usefulness of any information, apparatus, product, or process disclosed, or represents that its use fould not infringe privately owned rights. Reference herein to any specific commercial products, process, or service by trade name, trademark, manufacturer, or otherwise, does not necessarily constitute or imply its endorsement, recommendation, or favoring by the United States Government or the University of California. The views and opinions of authors expressed herein do not necessarily state or reflect those of the United States Government or the University of California, and shall not be used for advertising or product endorsement purposes.

This report has been reproduced

directly from the best available copy.

Available to DOE and DOE contractors from the Office of Scientific and Tèchnical Information

P.O. Box 62, Oak Ridge, TN 37831

Prices available from (615) 576-8401, FTS 626-8401

Available to the public from the

National Technical Information Service

US. Department of Commerce

5285 Port Royal Rd.

Springfield, VA 22161 


\title{
ELECTROCHEMICAL CORROSION STUDIES OF CONTAINER MATERIALS IN REPOSITORY-RELEVANT ENVIRONMENTS
}

\author{
by \\ A. K Roy \\ Framatome Cogema Fuels \\ and \\ G. A. Henshall and \\ R. D. McCright \\ Lawrence Livermore National Laboratory
}

December 12, 1995

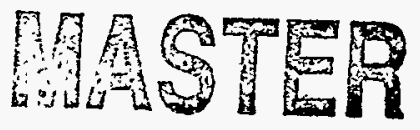

DISTRIBUTION OF THS DCCUNENT IS UNLAMITED 


\begin{abstract}
The Office of Civilian Radioactive Waste Management (OCRWM) of the United States Department of Energy (USDOE) is evaluating Yucca Mountain in southern Nevada to determine its suitability as a site for a mined geologic disposal system for the disposal of spent fuel and high-level nuclear waste. Framatome Cogema Fuels (FCF), as a part of the Management and Operating (M\&O) team in support of the Yucca Mountain Site Characterization Project (YMP), is responsible for designing and developing the waste package for this potential repository. As part of this effort, Lawrence Livermore National Laboratory (LLNL), also a member of the M\&O team, is responsible for testing materials and developing models for the materials to be used in the waste package. Based on a literature review of the anticipated degradation modes that may occur under the repository-relevant environmental conditions, LLNL has identified a large number of engineering materials for the various components of the waste package. One step in evaluating the performance of these materials is to conduct preliminary tests under these repository-relevant environmental conditions. This report is aimed at presenting the results of scoping electrochemical cyclic potentiodynamic polarization (CPP) experiments using nine candidate waste package container materials in various environments.
\end{abstract}

\title{
1. Introduction
}

The current waste package design effort is focused on all-metallic multi-barrier concepts to accommodate multi-purpose canisters (MPCs), uncanistered spent fuel, and defense high-level waste glass canisters. This design incorporates an outer corrosion-allowance metal barrier over the inner container, which is made of a suitable corrosion-resistant alloy. The corrosion-allowance barrier, which will be thicker than the inner corrosionresistant barrier, is being designed to undergo environment-induced degradation at a very slow rate, thus providing the inner container protection from the potential repository environment for a prolonged service period.

While a wide variety of degradation modes can occur on corrosion-resistant metallic materials in an aqueous environment, we consider localized corrosion such as pitting to be one of the more important modes with regard to limitations on container material performance. This type of degradation is one of the most destructive and insidious forms of corrosion, and requires an extended initiation period before visible pits appear. This period ranges from months to years, depending on the specific metal and the environment. Pitting is an autocatalytic process, inasmuch as the corrosion processes within a pit produce conditions that are both stimulating and necessary for the continuing activity of the pit. Generally speaking, pitting may be considered as an intermediate stage between complete corrosion resistance and general overall corrosion.

Preliminary cyclic potentiodynamic polarization (CPP) experiments were conducted at Lawrence Livermore National Laboratory (LLNL) to evaluate the susceptibilities of nine candidate waste package container materials, both corrosion-resistant and intermediate 
corrosion-resistant, to pitting corrosion in various repository-relevant environments. It is the purpose of this report to present the results of these scoping electrochemical tests.

\section{Materials and Environments}

A list of materials tested and their bulk chemical compositions are shown in Table 1. In addition to nickel-rich Alloy 825, which has been previously ${ }^{(1)}$ studied at LLNL, other corrosion-resistant materials such as Alloys G-3, C-4 and C-22 and Ti Grade-12 were included in this test program Alloy G-3 is comparable in composition to Alloy 825, but has increased molybdenum (Mo) content for enhanced resistance to localized corrosion. Alloys C-4 and C-22, both nickel-chromium-molybdenum (Ni-Cr-Mo) alloys, have been identified by LLNL as alternative metallic materials for the inner container because of their high-temperature stability and superior overall corrosion resistance compared to other NiCr-Mo alloys available today. A titanium-base alloy, Ti Grade-12, was selected for testing also in view of its outstanding corrosion resistance, and its useful combination of low density and high strength.

Austenitic Types 304 and 316L stainless steels were included in this testing program to compare the generated data to those existing in current literature. Type $316 \mathrm{~L}$ stainless steel, an ASME Boiler and Pressure Vessel Code ${ }^{(2)}$ material, is currently being considered by the Waste Storage and Transportation component of the M\&O to be the primary material for the MPC shell. Some moderately corrosion-resistant materials such as the nickel-copper Alloy 400, and 70/30 Cupronickel (CDA 715 $5^{(3)}$ ) were also tested. We believe that, under a dominantly wet repository environment, the outer container made of corrosion-allowance material such as carbon steel (ASTM A 516) might suffer badly from microbiologically-influenced corrosion (MIC), which can occur directly or indirectly as a result of activity of living microorganisms. Alloy 400 and 70/30 Cupronickel are considered to provide better resistance to MIC under such environmental conditions, because of the presence of copper and nickel in these materials.

Although the groundwater in the vicinity of the proposed repository (Well J-13) is known to have a near-neutral to slightly alkaline $\mathrm{pH}$, and to be benign to corrosion-resistant materials, we performed tests in three aqueous environments namely, neutral, acidified, and alkalized, concentrated brines at room temperature, $60^{\circ} \mathrm{C}$, and $90^{\circ} \mathrm{C}$, for reasons described below. All test solutions, prepared with distilled water, contained 52.6 grams per liter of reagent-grade sodium chloride. Acidification was done by adding 0.055 milliliter per liter of sulfuric acid to the brine. Calcium hydroxide was added at 0.074 grams per liter to prepare the alkaline salt solution. The $\mathrm{pH}$ for neutral, acidic, and alkaline salt solutions ranged between 6 and 7,2 and 3, and 10 and 11, respectively.

The neutral, concentrated brine was selected to simulate a dry-out condition followed by resaturation, causing concentration of ionic salts. The acidified, concentrated salt solution was used to represent an extreme case in which microbial corrosion occurs as a result of reactions between certain man-made materials (diesel fuels, organics, and sulfurcontaining compounds) and water. These materials may be introduced into the repository 
during construction and operation, and may not be removed or may be inadvertently left behind when operations cease. The acidic $\mathrm{pH}$ can also simulate some of the effects of radiolysis. The alkalized, concentrated brine simulates reactions between man-made materials such as concretes or grouts, which may be used in construction of the emplacement drifts, and the aqueous environment.

\section{Experimental Procedure}

A three-electrode technique was employed to conduct CPP experiments in a Pyrex corrosion cell that contained a cylindrical working electrode, two graphite counter electrodes, and a Luggin capillary connected to a reference electrode. Prior to conducting the CPP tests, a few calibration experiments ${ }^{(4)}$ were performed in deaerated $1.0 \mathrm{~N} \mathrm{H}_{2} \mathrm{SO}_{4}$ solution at $30^{\circ} \mathrm{C}$ using Type 430 stainless steel specimen to obtain the standard. potentiodynamic polarization plots, and to verify the reproducibility of the instrumentation. While a saturated calomel reference electrode (SCE) was used at ambient temperature and $60^{\circ} \mathrm{C}, \mathrm{Ag} / \mathrm{AgCl}$ was used at $90^{\circ} \mathrm{C}$ as the reference electrode. The cylindrical specimens were polished with 600 grit paper and cleaned with distilled water, acetone, and ethanol prior to their exposure to the test solutions. Potential was applied to the test specimens using a Model 273 potentiostat, controlled by an IBM-conpatible PC with Model 252/352 Softcorr II software, both manufactured by EG\&G Instruments, Princeton Applied Research. A controlled-temperature water bath maintained the test temperature at the desired value within $\pm 0.1^{\circ} \mathrm{C}$. For tests at elevated temperatures, a Pyrex condenser was fitted to one port of the cell to capture evaporated water and return it to the test cell.

Initially, each specimen was found to reach its stable open-circuit or corrosion potential $\left(E_{\text {corr }}\right)$ after about an hour in solution. The working electrode was then anodically polarized by scanning the potential at the ASTM-specified ${ }^{(4)}$ rate of 0.17 millivolt per second. The values of current corresponding to the applied potential were automatically recorded, and the resulting polarization curve was displayed as potential versus log current density plots on the computer monitor. After polarization to $+200 \mathrm{mV}$ (SCE or $\mathrm{Ag} / \mathrm{AgCl}$, +441 or $+422 \mathrm{mV}$, SHE ), the direction of polarization was reversed at the same potential scan rate to $E_{\text {corr }}$. Upon completion of the test, the data were saved, and the CPP plot was printed.

The $\mathrm{pH}$ of the test solution was measured at room temperature both before and after each experiment. At the conclusion of each test, the specimen was cleaned with distilled water, acetone, and ethanol. The cleaned specimen was visually examined, followed by a microscopic examination to detect the presence or absence of pitting. The specimen underwent further metallographic evaluation if pits were detected by optical microscopy. A limited number of potentiostatic polarization experiments was also performed at controlled electrochemical potentials to evaluate pit growth in susceptible materials. 


\section{Results and Discussion}

Chloride ion (Cl) has long been known to act as an aggressive species for pitting of active-passive metals and alloys such as austenitic Types 304 and 316 stainless steels. ${ }^{(5-7)}$ Broadly speaking, the initiation of pitting is the result of the breakdown of the passive film on these materials resulting from the presence of certain anions such as $\mathrm{Cl}^{-}$, and the subsequent establishment of an electrochemical cell in which the damaged site acts as an anode and the surrounding passive surface acts as a cathode. The results obtained from this investigation indicate that both Types 304 and $316 \mathrm{~L}$ stainless steels are susceptible to severe pitting corrosion in neutral, acidic, and alkaline, concentrated brines at $60^{\circ} \mathrm{C}$ and $90^{\circ} \mathrm{C}$. No localized attack was observed with these materials in the neutral solution at room temperature, but a slight pitting tendency was observed in Type 316L stainless steel in the other two environments at ambient temperature.

From an electrochemical point of view, the initiation of pitting occurs at a critical potential, $\mathrm{E}_{\mathrm{pit}}$, which is used as a measure of resistance to pitting corrosion. As shown schematically in Figure 1 under idealized conditions, at $\mathrm{E}_{\text {pit }}$ the slope of the anodic potentiodynamic polarization curve changes abruptly showing a dramatic increase in current density. The more noble $\mathrm{E}_{\mathrm{pit}}$ is, that is the higher its value, the more resistant the material is to pitting attack. For susceptible metals and alloys, as the direction of polarization is reversed after some degree of anodic polarization above $\mathrm{E}_{\mathrm{pit}}$, a hysteresis is observed in which the return polarization curve follows an active (higher current) path, compared to the initial anodic one. The crossover at the passive current density defines a repassivation or protection potential, $\mathrm{E}_{\text {prot }}$, below which established pits are presumed not to continue to grow. By contrast, new pits only initiate at potentials above $\mathrm{E}_{\mathrm{pit}}$. Between $\mathrm{E}_{\text {prot }}$ and $\mathrm{E}_{\mathrm{pit}}$, new pits cannot initiate, but old ones can still grow.

Results indicate that Type $316 \mathrm{~L}$ stainless steel is susceptible to pitting attack in acidic and alkaline salt solutions at all three test temperatures. While both Types 304 and $316 \mathrm{~L}$ stainless steels showed discernible $\mathbf{E}_{\mathrm{pit}}$ values in all three tested environments at elevated temperatures, neither of these materials showed any repassivation behavior following reversal of the potential scan, since the return polarization curve did not intersect the passive current density. Instead, an active curve was noted after the forward scan curve. Vigorous bubble formation was observed at the graphite counter electrodes in all elevated temperature tests involving these two materials at potentials where the slope of the forward polarization curve suddenly changed, showing a marked increase in current density. The maximum current density attained just prior to scan reversal was sufficiently high (approximately of the order of $0.10 \mathrm{amp} / \mathrm{cm}^{2}$, or more) to eventually accumulate black corrosion products in the test solutions. The CPP curves for Type 304 stainless steel in alkaline, concentrated salt solutions at $60^{\circ} \mathrm{C}$ and $90^{\circ} \mathrm{C}$ are shown in Figures 2 and 3 , respectively. Figure 4 shows the CPP diagram for Type 316L stainless steel in acidified, concentrated brine at ambient temperature, with both $\mathrm{E}_{\text {pit }}$ and $\mathrm{E}_{\text {prot }}$ identified.

One interesting observation was that the nickel-rich Alloy 825 , which is currently the primary candidate for the inner containment barrier material, suffered from pitting 
corrosion following exposure to neutral and acidic, concentrated salt solutions at $90^{\circ} \mathrm{C}$, the extent of pitting being more pronounced in the latter environment. Figure 5 shows the CPP diagram for Alloy 825 tested in acidic, concentrated brine at $90^{\circ} \mathrm{C}$, with identification of both $E_{\text {pit }}$ and $E_{\text {prot }}$ A macroscopic view of the cylindrical specimen of Alloy 825, that contained numerous pits around its circumference, is illustrated in Figure 6.

Alloy G-3, which contains more molybdenum (Mo) than Alloy 825, also underwent pitting and subsequent dissolution in acidic solution at $90^{\circ} \mathrm{C}$. Such behavior is in contrast to a general belief that an increased Mo content alone might enhance the pitting corrosion resistance of Alloy 825 in a chloride-containing aqueous environment. It is possible that the test environment is so aggressive that Mo alone cannot prevent the localized breakdown of the protective surface films on Alloy G-3. In light of these results, it appears advisable to evaluate Alloy G-30, another nickel-rich material, that contains more chromium (Cr) than Alloy G-3, and more Mo than Alloy 825.

With respect to the electrochemical corrosion behavior of intermediate corrosion-resistant materials, both Alloy 400 and 70/30 Cupronickel were readily susceptible to dissolution in all three environments, both at ambient and elevated temperatures. The specimen surfaces were rough and discolored at the conclusion of the tests. Thick orange-colored corrosion products were seen floating in the solutions, suggesting that elemental nickel, relatively electronegative compared to copper $(-250 \mathrm{mV}$ versus $+337 \mathrm{mV}$, SHE), might have undergone preferential dissolution in response to the application of potential during the CPP experiments. As with austenitic stainless steels, the maximum current density attained just prior to the potential scan reversal was quite high.

Results indicate that of all the materials tested, Alloy C-4, Alloy C-22, and Ti Gr-12 demonstrated the maximum corrosion resistance in all environments tested. Neither pitting nor dissolution was observed with these three highly corrosion-resistant materials. They also maintained their shiny surface appearances even after exposure to the test solutions. A typical CPP curve for these types of materials is illustrated in Figure 7, which does not exhibit a clockwise hysteresis effect upon reversal of potential scan. Instead, the CPP curve consistently showed a counter-clockwise path following scan reversal, which was limited to a very low current density (approximately of the order of $10^{-6} \mathrm{amp} / \mathrm{cm}^{2}$ or less). The prèsence or absence of clockwise hysteresis correlates well with the modes of corrosion observed on the specimens after the CPP tests. For example, pitting corrosion occurred only on materials such as Types 304 and 316L stainless steels, Alloy 825, and Alloy G-3 that displayed a well-defined clockwise hysteresis. A macroscopic view of all specimens following CPP experiments in acidic concentrated brine at $90^{\circ} \mathrm{C}$ is shown in Figure 8 for comparison. The overall results are presented in Tables 2 through 10.

\subsection{Effects of $\mathrm{pH}$ and Temperature}

An attempt has been made to analyze the effects of $\mathrm{pH}$ and temperature on open circuit or corrosion potential $\left(E_{\text {corr }}\right)$. Figures 9-11 show the effects of $\mathrm{pH}$ on $E_{\text {corr }}$ at ambient temperature, $60^{\circ} \mathrm{C}$ and $90^{\circ} \mathrm{C}$, respectively, for all nine materials tested. An examination of 
these plots reveals that at room temperature and $60^{\circ} \mathrm{C}$, Alloys $825, \mathrm{G}-3, \mathrm{C}-4$ and C-22 and Ti Gr-12, showed a similar trend, in that the $E_{\text {cor }}$ was shifted to more negative values with increasing $\mathrm{pH}$. It has been showi ${ }^{(8)}$ that the effect of $\mathrm{pH}$ change on electrochemical potential is dependent on the concentration of the dissolved species. The $\mathrm{pH}$ is related to hydrogen concentration or amount of acid, and is defined as the negative of base ten logarithm of the hydrogen ion activity. Considering an equilibrium between hydrogen gas and an acid solution, it can be shown thermodynamically (Nernst Equation) that the value of $\mathrm{E}_{\text {cor }}$ would be more positive as $\mathrm{pH}$ becomes more acidic, as observed here.

The importance of the hydrogen ion lies in its ability to interact with the alloy surface. It is worth mentioning at this point that the amount of hydrogen bubbles formed at the graphite counter-electrodes was negligible implying that no significant corrosion was occurring on the specimen surfaces of these five materials during their tests at room temperature and $60^{\circ} \mathrm{C}$. This was verified by both visual examination and optical microscopy of test specimens at the conchusion of the tests, showing no signs of localized corrosion and/or dissolution. At $90^{\circ} \mathrm{C}$, however, the nickel-rich Alloy 825 exhibited pitting susceptibility in both neutral and acidic, concentrated brine, with increased attack in the latter environment. Furthermore, the higher molybdenum-containing Alloy G-3 suffered from both pitting and dissolution in the acidic solution at the same temperature. An evaluation of the $\mathrm{E}_{\text {corr }}$ versus $\mathrm{pH}$ plots at $90^{\circ} \mathrm{C}$ shows that nickel-base Alloys $\mathrm{C}-4$ and $\mathrm{C}-22$, as well as titanium-base alloy Ti Gr-12, demonstrated a pattern which is similar to those at the other two test temperatures. This behavior is consistent in view of the absence of localized attack in these materials in all environments tested. It is, however, not clear why Alloy G-3, which underwent pitting and dissolution in the acidic brine at $90^{\circ} \mathrm{C}$, would show a similar trend in the $\mathrm{E}_{\text {corr }}$ versus $\mathrm{pH}$ plot.

As mentioned earlier, both Types 304 and $316 \mathrm{~L}$ stainless steels showed a propensity to severe pitting corrosion in all three environments at $60^{\circ} \mathrm{C}$ and $90^{\circ} \mathrm{C}$. At ambient temperature, a slight pitting tendency was observed only with Type $316 \mathrm{~L}$ stainless steel in acidic and alkaline solutions. An examination of the $\mathrm{E}_{\text {corr }}$ versus $\mathrm{pH}$ plots indicates that, except in room temperature tests involving Type 304 stainless steel, in which no pitting occurred, the $\mathrm{E}_{\text {cor }}$ value was more positive for these two austenitic stainless steels at both the neutral and alkaline $\mathrm{pH}$ than in the acidic brine. A significant amount of black corrosion product was seen floating in all three environments at the conchusion of tests performed at $60^{\circ} \mathrm{C}$ and $90^{\circ} \mathrm{C}$. No analyses of these corrosion products have been performed to date.

An examination of the $\mathrm{E}_{\text {cor }}$ versus $\mathrm{pH}$ plots for Alloy 400 and $70 / 30$ Cupronickel indicates a mixed trend. For example, at ambient temperature, the corrosion potential for both these alloys in an acidic brine shifts to a slightly lower (negative) value at neutral $\mathrm{pH}$, followed by a sharp rise for the alkaline solution. However, at $60^{\circ} \mathrm{C}$, the most positive $\mathrm{E}_{\text {corr }}$ value for Cupronickel was attained in a neutral brine. Finally, the maximum $\mathrm{E}_{\text {corr }}$ values for both these alloys were once again achieved in the alkaline solution at $90^{\circ} \mathrm{C}$. No explanation can be provided at this time for the effects observed in these plots. 
Figures 12 through 20 show the effect of temperature on $E_{\text {corr }}$ for each individual material as a function of $\mathrm{pH}$. An evaluation of these data suggests that there is no consistent trend. There are indications in the literature ${ }^{(9)}$ that the solution temperature can influence the onset of localized attack of susceptible metals and alloys in environments containing $\mathrm{Cl}$. - However, the data generated in this investigation do not reveal a consistent effect of test temperature on the critical pitting potential, $E_{\text {pit. }}$ For example, for Type $316 \mathrm{~L}$ stainless steel immersed in the alkaline salt solution, $E_{\text {pit }}$ was gradually reduced to more negative values as the test temperature was increased from ambient to $60^{\circ} \mathrm{C}$ to $90^{\circ} \mathrm{C}$ (i.e., +381 , +182 , and $+102 \mathrm{mV}$, respectively, versus SHE). On the other hand, in the acidic solution, $\mathrm{E}_{\mathrm{pit}}$ was increased to a more positive value (i.e., from +171 to $+352 \mathrm{mV}$, respectively, versus SHE) with an increase in temperature from $60^{\circ} \mathrm{C}$ to $90^{\circ} \mathrm{C}$. A similar discrepancy was also observed for Type 304 stainless steel in these environments. Nevertheless, despite these inconsistencies in the temperature effects on $E_{\text {corr }}$ and $E_{\text {pit }}$, austenitic stainless steels incorporated in the present study underwent extensive pitting both at $60^{\circ} \mathrm{C}$ and $90^{\circ} \mathrm{C}$.

Temperature is a very complex external variable. Numerous studies ${ }^{(10-13)}$ in the effect of temperature on $\mathrm{E}_{\text {pit }}$ for various susceptible alloys have been reported. Study by SzklarskaSmialowska ${ }^{(10)}$ indicates that for Cr-Ni-Mo stainless steel, $\mathrm{E}_{\text {pit }}$ becomes more active with increasing temperature up to $70^{\circ} \mathrm{C}$, beyond which it attains a constant vahue. Horvath and Uhlig ${ }^{(1)}$ found that in a chloride solution at $0^{\circ} \mathrm{C}$, the $\mathrm{E}_{\text {pit }}$ values of stainless steels decreased with increased Mo concentration, but at $25^{\circ} \mathrm{C}$, an opposite trend was observed. Study by Tousek ${ }^{(12)}$ revealed that for $\mathrm{Cr}-\mathrm{Ni}$ stainless steel exposed to an alkaline brine, $\mathrm{E}_{\mathrm{pit}}$ became more negative with a change in temperature from $6^{\circ} \mathrm{C}$ to $40^{\circ} \mathrm{C}$, but at higher temperatures, decreases in $\mathrm{E}_{\mathrm{pit}}$ were less pronounced. For Types 304 and 316 stainless steels, a significant decrease in $\mathrm{E}_{\mathrm{pit}}$ was observed ${ }^{(13)}$ in a neutral brine at temperatures ranging between $25^{\circ} \mathrm{C}$ and $220^{\circ} \mathrm{C}$, followed by a slight increase at higher temperatures. Such inconsistencies thus far have not been fully explained, but appear to stem from the fact that the multiple processes that occur during pitting each have their own individual temperature dependence. ${ }^{(7)}$

In view of the preceding discussion, it should be recognized that complex interrelationships can exist among different environmental variables such as $\mathrm{pH}$, potential, concentration, and temperature. The combined effects of these parameters not only influence the overall corrosion process but also affect the action of each variable. The inference is strong that the effect of one variable can be dependent on the magnitude of another, thus, influencing the electrochemical behavior of materials of interest. One implication of this finding is that great care must be taken in designing and interpreting the results of "accelerated" tests from which extrapolations are made regarding long-term corrosion performance.

\section{Application to Pitting Model Development}

The experimental results presented in the preceding section can be applied to the development of pitting models. A stochastic pit initiation and growth model is currently 
under development for use in the design and performance assessment of high-level radioactive-waste containers. ${ }^{(14-1)}$ In the stochastic model, the pit initiation process is controlled by three key parameters: (1) the "birth probability", $\lambda$, for the initiation of a breakdown in the passive film protecting the metal, (2) the "death probability", $\mu$, for the repassivation of this defect, and (3) the critical amount of time a breakdown in the passive film must exist before it grows to become a permanent, macroscopic pit, $\tau_{c}$. The growth of pits is also considered to be stochastic, and is controlled by a growth probability, $\gamma$, and a permanent pit cessation probability, $\eta{ }^{(16)}$ Each of these parameters is influenced by the alloy composition and the corrosion environment; to date, the electrochemical potential, $\mathrm{Cl}^{-}$, and temperature have been explicitly included in the model. This section describes the two major ways in which the CPP experiments can be used in the further development of this model: (1) directly, to evaluate particular parameters in the model, and (2) indirectly, to guide other experiments specifically designed to evaluate the model parameters.

The data generated by the CPP experiments can be directly used to evaluate two parameters in the current stochastic model. First, the dependence of $\lambda$ on the applied potential, $E_{a p p}$, is given by the following equation: ${ }^{(14,15)}$

$$
\lambda \propto \alpha\left(E_{\text {app }}-E_{c}\right),
$$

where $\alpha$ is a constant, and $E_{c}$ is the critical potential below which pit initiation cannot occur. Taking the pitting potential determined in the CPP experiments as the potential below which pitting cannot initiate, $E_{\text {pit }}$ can be equated to the parameter $E_{c}$ in equation (1). Second, the pit growth probability is assumed to depend on the applied potential according to the following equation: ${ }^{(14,15)}$

$$
\gamma \propto\left(\mathrm{E}_{\text {app }}-\mathrm{E}_{\mathrm{crt}}\right)^{\mathrm{b}},
$$

where $b$ is a constant (equal to 0.5 for hemispherical pits), and $E_{c t r}$ is the critical potential below which existing pits do not grow. Taking the $E_{\text {prot }}$ determined in the CPP experiments as the potential below which existing pits cannot grow, it can be equated to the parameter $E_{c t t}$ in equation (2). As discussed elsewhere ${ }^{(15)}$, the effects of potentiodynamic scan rate on these critical potentials can be easily accounted for.

The results of CPP experiments also can be used indirectly to guide experiments specifically designed to evaluate other model parameters. First, for potentials near the measured $E_{\mathrm{pit}}$, potentiostatic polarization experiments can be performed to evaluate several of the parameters related to pit initiation, such as the critical time $\left(\tau_{c}\right)$ necessary to establish a pit after a breakdown in the passive film. Second, the $E_{\text {pit }}$ value measured by CPP can be used to determine an electrochemical potential at which pit growth parameters (e.g. $\gamma$ and $\eta$ ) can be successfully evaluated under potentiostatic control. For example, the results shown in Table 5 indicate an $E_{\text {pit }}$ value of $+146 \mathrm{mV}$ versus SHE for Type 316L stainless steel in the neutral brine at $60^{\circ} \mathrm{C}$. As shown in Figure 21, potentiostatic exposure for 60 minutes in this environment at $+281 \mathrm{mV}$ versus SHE, well above $E_{\text {pit }}$, results in extensive pitting. It should be noted that both the pit depth and pit diameter distributions 
are observed to be bimodal, suggesting that they may be correlated. Figure 21(c) shows that the pit aspect ratios (i.e. the ratio of the pit depth to diameter) are all less than one, meaning that the pits are relatively shallow for their diameter. Similarly, Table 9 indicates an $E_{\text {pit }}$ value of $+352 \mathrm{mV}$ versus SHE for Alloy 825 tested in acidic concentrated brine at $90^{\circ} \mathrm{C}$. As expected, pitting has been observed under potentiostatic control at potentials ranging from +372 to $+402 \mathrm{mV}$ versus SHE; the number and depth of pits appear to increase with increasing potential. Figure 22 presents the results obtained at an applied potential of $+392 \mathrm{mV}$, showing distributions in pit depth, diameter and aspect ratio, all with a single mode.

The key point for the preceding discussion is that the $E_{\text {pit }}$ values measured in the CPP experiments can be used to define the potentials at which distributions such as those in Figures 21 and 22 can be measured for a given alloy and environment. From these distributions, parameters such as $\gamma$ and $\eta$ can be measured for use in pitting model development and verification.

\section{Conclusion}

Electrochemical CPP experiments were performed in neutral, acidic, and alkaline, concentrated brines at ambient and elevated temperatures on nine candidate waste package container materials. Of all the materials tested, nickel-base Alloys $\mathrm{C}-4$ and $\mathrm{C}-22$, and. titanium-base $\mathrm{Ti} \mathrm{Gr}-12$ exhibited the maximum corrosion resistance in all environments. Neither pitting corrosion nor dissolution was observed with these three highly corrosion-resistant materials. Nickel-rich Alloy 825, which is the current primary candidate for the inner container material, suffered from pitting attack in the neutral and acidic solutions at $90^{\circ} \mathrm{C}$, the extent of pitting being much more pronounced in the latter environment. Alloy G-3, a higher molybdenum-containing nickel-rich alloy, also showed a severe pitting tendency in the acidic brine at $90^{\circ} \mathrm{C}$.

Austenitic Types 304 and 316L stainless steels showed a propensity to severe pitting corrosion in all three environments, particularly at $60^{\circ} \mathrm{C}$ and $90^{\circ} \mathrm{C}$. Alloy 400 and $70 / 30$ Cupronickel were readily susceptible to corrosion in all environments, both at ambient and elevated temperatures. The maximum current density attained during the CPP tests involving these four materials was significantly high compared to that for the other materials tested. While black reaction products were seen with the stainless steels, thick orange-colored corrosion products were observed with Alloy 400 and 70/30 Cupronickel, suggesting that the relatively electronegative nickel might have been preferentially dissolved as a result of the high current drawn during the CPP experiments.

Finally, an effort was made to correlate $\mathrm{E}_{\text {cor }}$ and $\mathrm{E}_{\mathrm{pit}}$ to the solution $\mathrm{pH}$ and temperature. No consistent pattern was observed. At least in the case of variations in temperature, the lack of a consistent pattern is to be expected based on previous studies cited in the literature. 


\section{Future Work}

The results from the present investigation indicate that both Alloys 825 and G-3 may become susceptible to pitting corrosion in acidified, concentrated brine at $90^{\circ} \mathrm{C}$. However, Alloy G-3 contains more molybdenum than Alloy 825 (6\% versus 3\% by weight in Alloy 825). The fact that Alloy G-3 underwent pitting and subsequent dissolution despite the presence of higher Mo content suggests that a higher grade of nickel-rich material should be evaluated for its corrosion resistance in a similar environment. One such material is Alloy G-30, which contains more Cr than Alloy G-3, and more Mo than Alloy 825.

The results obtained from these scoping electrochemical corrosion tests have enabled us to screen a host of candidate materials, and to identify a group of prospective container materials having the desired corrosion resistance. However, no effort has yet been made to verify the reproducibility of pitting corrosion in susceptible materials. Therefore, future efforts will be focused on repeating some selected CPP experiments, and performing potentiostatic polarization experiments in susceptible environments involving this group of materials to evaluate pit growth at a controlled electrochemical potential. Attempts will also be made to analyze the corrosion products in the test solutions.

\section{Acknowledgments}

This work was supported by the U.S. Department of Energy, Office of Civilian Radioactive Waste Management, Yucca Mountain Site Characterization Office, Las Vegas, NV, and performed under the auspices of the U.S. Department of Energy by the Lawrence Livermore National Laboratory under contract number W-7405-ENG-48 and by TRW Environmental Safety Systems Inc. under contract number DE-AC01-RW00134.

The assistance of Steve Gordon in performing the experimental work is thankfully acknowledged. Acknowledgment is also made to Dennis Fleming for his help in computer plotting of the experimental data.

\section{References}

1. R. D. McCright and D. L. Fleming, "Electrochemical Polarization Measurements on Pitting Corrosion Susceptibility of Nickel-Rich Alloy 825," UCRL-JC-107065, Lawrence Livermore National Laboratory (1991)

2. "Specification for Heat-Resisting Chromium and Chromium-Nickel Stainless Steel Plate, Sheet, and Strip for Pressure Vessels," ASME Specification: SA-240, 1990

3. "Standard Specification for Copper-Alloy Plate and Sheet for Pressure Vessels, Condensers and Heat Exchangers," ASTM Designation: B 171/B 171M-91a

4. "Standard Reference Test Method for Making Potentiostatic and Potentiodynamic Anodic Polarization Measurements," ASTM Designation: G 5-87 (1989) 
5. A. J. Sedricks, Corrosion of Stainless Steels, Wiley, New York (1979)

6. J. R Galvele, "Passivity of Metals" (Eds R. P. Frankenthal and J. Kruger), p. 285. Electrochem Soc., New Jersey (1978)

7. Z. Szklarska-Smialowska, Pitting Corrosion of Metals, NACE, Houston, Texas, p. 201 (1986)

8. D. C. Silverman, "Presence of Solid $\mathrm{Fe}(\mathrm{OH})_{2}$ in EMF-pH Diagram for Iron," Corrosion, Vol. 38 (No. 2), p. 453 (1982)

9. J. W. Oldfield, T. S. Lee, and R. M. Kain, "Avoiding Crevice Corrosion of Stainless Steels," in Proceedings of Stainiless Steels '84, p. 205, Institute of Metals (1985)

10. Z. Szklarska-Smialowska, "The Pitting of Iron-Chromium-Nickel Alloys," Localized Corrosion, NACE-3, R. Staehle, B. Brown, J. Kruger, A. Agrawal, Eds., NACE, Houston, Texas, p. 312 (1974)

11. J. Horvath and H. H. Uhlig, J. Electrochem. Soc., Vol. 115, p. 791 (1968)

12. J. Tousek, Werkst. Korros., Vol. 28, p. 619 (1977)

13. F. A. Posey, A. A. Palko, A. L. Bacarella, Report ORNL/TM-6303 (1978)

14. G. A. Henshall, "Modeling Pitting Corrosion Damage of High-level RadioactiveWaste Containers Using a Stochastic Approach, "J. Nuclear Mater. Vol 195, p. 109 (1992)

15. G. A. Henshall, "Stochastic Modeling of the Influence of Environment on Pitting Corrosion Damage of Radioactive-Waste Containers," in Proc. Scientific Basis of Nuclear Waste Management - XVII, Materials Research Society, Pittsburgh, PA, p. $679(1995)$

16. G. A. Henshall, "A Phenomenological Approach to Simulating the Evolution of Radioactive-Waste Container Damage Due to Pitting Corrosion," in Proc.

Scientific Basis of Nuclear Waste Management - XIX, Materials Research Society, Pittsburgh, PA, submitted (1995) 
Table 1

Chemical Composition of Materials Tested (wt\%)

\begin{tabular}{|c|c|c|c|c|c|c|c|c|c|c|c|c|c|c|}
\hline Material & Heat \# & $\underline{\mathrm{C}}$ & $\underline{\mathrm{Mn}}$ & $\underline{\mathbf{P}}$ & $\underline{\mathbf{S}}$ & $\underline{\mathrm{Si}}$ & $\underline{\mathrm{Ni}}$ & $\underline{\mathrm{Cr}}$ & $\underline{\text { Mo }}$ & $\underline{\mathrm{Fe}}$ & $\underline{\mathbf{T i}}$ & Al & $\underline{\mathrm{Cu}}$ & Others \\
\hline Type 304 SS & $\mathrm{K} 299$ & 0.07 & 1.55 & 0.031 & 0.009 & 0.48 & 10.18 & 19.90 & 0.10 & Bal & - & - & 0.10 & $\mathrm{~N}-0.05$ \\
\hline Type 316L SS & $16650^{*}$ & $\begin{array}{l}0.03 \\
(\max )\end{array}$ & $\begin{array}{l}2.00 \\
(\max )\end{array}$ & $\begin{array}{l}0.03 \\
(\max )\end{array}$ & $\begin{array}{l}0.03 \\
(\max )\end{array}$ & $\begin{array}{l}0.75 \\
(\max )\end{array}$ & $\begin{array}{l}10.00 \\
-14.00\end{array}$ & $\begin{array}{l}16.00 \\
-18.00\end{array}$ & $\begin{array}{l}2.00 \\
-3.00\end{array}$ & Bal & - & - & - & $\mathrm{N}-0.10(\max )$ \\
\hline Alloy 825 & HH3884FG & 0.03 & - & - & 0.001 & 0.33 & 39.84 & 22.11 & 3.40 & Bal & 0.88 & 0.70 & 1.80 & - \\
\hline Alloy G-3 & 1298558857 & 0.004 & 0.80 & 0.009 & 0.003 & 0.36 & Bal & 22.26 & 6.88 & 19.29 & - & - & 1.90 & $\begin{array}{l}(\mathrm{Nb}+\mathrm{Ta})-\cdot 0.30 ; \mathrm{W}-0.85 \\
\mathrm{Co}-1.01\end{array}$ \\
\hline Alloy C-4 & 1245550905 & 0.004 & 0.16 & 0.006 & 0.006 & 0.02 & Bal & 15.66 & 15.49 & 0.25 & 0.21 & - & - & $\mathrm{Co}-0.10$ \\
\hline Alloy C-22 & 1227793285 & 0.004 & 0.26 & 0.008 & 0.002 & - & Bal & 21.80 & 13.60 & 4.70 & - & - & - & W-3.20;V-0.14;Co-1.65 \\
\hline Ti Grade-12 & G9557 & 0.0075 & & - & - & - & 0.75 & - & 0.30 & 0.13 & Bal & - & - & $\begin{array}{l}\mathrm{O}-0.14 ; \mathrm{N}-0.0065 \\
\mathrm{Y}-<0.0050 ; \mathrm{H}-0.0016\end{array}$ \\
\hline Alloy 400 & D068 & 0.050 & 1.01 & - & 0.007 & 0.05 & 66.46 & - & - & 0.93 & - & 0.002 & 31.49 & - \\
\hline CDA 715** & Unknown & - & $\begin{array}{l}1.00 \\
(\max )\end{array}$ & - & - & - & $\begin{array}{l}29.00 \\
-33.00\end{array}$ & - & - & $\begin{array}{l}0.40 \\
-1.00\end{array}$ & - & - & $\mathrm{Bal}$ & $\begin{array}{l}\mathrm{Pb}-0.05(\max ) \\
\mathrm{Zn}-1.00(\max )\end{array}$ \\
\hline
\end{tabular}


Table 2

Results of Cyclic Potentiodynamic Polarization (CPP) Tests at Ambient Temperature in Neutral Salt Solution*

\begin{tabular}{|c|c|c|c|c|c|}
\hline Material Tested & $\underline{\mathrm{pH}}$ & $\frac{\mathrm{E}_{\mathrm{com}}(\mathrm{mV})}{\mathrm{SCE}(\mathrm{SHE})}$ & $\underline{E}_{\mathrm{pit}}(\mathrm{mV})$ & $\underline{E}_{\text {prot }}(\mathrm{mV})$ & Observation \\
\hline Type 304 SS & 6.62 & $-176(+65)$ & NA & NA & NLC \\
\hline Type 316L SS & 6.70 & $-118(+123)$ & $\mathrm{NA}$ & NA & NLC \\
\hline Alloy 825 & 6.87 & $-132(+109)$ & NA & NA & NLC \\
\hline Alloy G-3 & 6.86 & $-106(+135)$ & NA & NA & NLC \\
\hline Alloy C-4 & 6.73 & $-213(+28)$ & NA & NA & NLC \\
\hline Alloy C-22 & 6.71 & $-141(+100)$ & $\mathrm{NA}$ & NA & NLC \\
\hline $\mathrm{Ti}$ Gr-12 & 6.48 & $-260(-19)$ & $\mathrm{NA}$ & NA & NLC \\
\hline Alloy 400 & 6.31 & $-212(+29)$ & NA & NA & DPA \\
\hline CDA 715 & 6.78 & $-232(+9)$ & NA & NA & DPA \\
\hline
\end{tabular}

$* 52.6 \mathrm{~g} / \mathrm{L}$ of $\mathrm{NaCl}$

Table 3

Results of CPP Tests at Ambient Temperature in Acidic Salt Solution**

\begin{tabular}{|c|c|c|c|c|c|}
\hline Material Tested & $\underline{\mathrm{pH}}$ & $\underline{\mathrm{E}}_{\mathrm{SCE}} \frac{(\mathrm{mV})}{(\mathrm{SHE})}$ & $\frac{E_{\mathrm{pit}}(\mathrm{mV})}{\mathrm{SCE}(\mathrm{SHE})}$ & $\frac{\mathrm{E}_{\mathrm{prot}}(\mathrm{mV})}{\mathrm{SCE}}$ & Observation \\
\hline Type 304 SS & 2.32 & $-131(+110)$ & NA & NA & NLC \\
\hline Type 316L sS & 2.54 & $-179(+62)$ & $+5(+246)$ & $-65(+176)$ & FSP \\
\hline Alloy 825 & 2.29 & $-99(+142)$ & NA & NA & NLC \\
\hline Alloy G-3 & 2.33 & $-38(+203)$ & NA & NA & NLC \\
\hline Alloy C-4 & 2.38 & $-73(+168)$ & NA & NA & NLC \\
\hline Alloy C-22 & 2.35 & $-27(+214)$ & NA & NA & NLC \\
\hline $\mathrm{Ti} \mathrm{Gr}-12$ & 2.35 & $-41(+200)$ & NA & NA & NLC \\
\hline Alloy 400 & 2.40 & $-170(+71)$ & NA & NA & DPA \\
\hline CDA 715 & 2.35 & $-208(+33)$ & NA & NA & DPA \\
\hline
\end{tabular}

$* * 52.6 \mathrm{~g} / \mathrm{L}$ of $\mathrm{NaCl}+0.055 \mathrm{~mL} / \mathrm{L}$ of $\mathrm{H}_{2} \mathrm{SO}_{4}$

Key to Abbreviation:

FSP: A few very small pits were observed.

NLC: No localized corrosion was observed. The maximum current density was very low. The specimen looked shiny throughout the test.

DPA : The specimen underwent severe dissolution. Alloying element, possibly nickel, might have dissolved preferentially.

NA: Not available from the CPP diagram

SCE : Saturated Calomel Electrode

SHE : Standard Hydrogen Electrode 
Table 4

Results of CPP Tests at Ambient Temperature in Alkaline Salt Solution*

\begin{tabular}{|c|c|c|c|c|c|}
\hline Material Tested & $\underline{\mathrm{pH}}$ & $\underline{E}_{\text {cor }}(\mathrm{mV})$ & $\underline{E}_{\mathrm{pit}}(\mathrm{mV})$ & $\underline{E}_{\text {prot }}(\mathrm{mV})$ & Observation \\
\hline & & $\overline{\mathrm{SCE}}$ (SHE) & SCE (SHE) & & \\
\hline Type 304 SS & 10.35 & $-193(+48)$ & NA & $\mathrm{NA}$ & NLC \\
\hline Type 316L SS & 10.64 & $-163(+78)$ & $+140(+381)$ & NA & FSP \\
\hline Alloy 825 & 10.34 & $-243(-2)$ & NA & NA & NLC \\
\hline Alloy G-3 & 10.99 & $-229(+12)$ & NA & $\mathrm{NA}$ & NLC \\
\hline Alloy C-4 & 10.98 & $-323(-82)$ & NA & NA & NLC \\
\hline Alloy C-22 & 10.87 & $-302(-61)$ & NA & $\mathrm{NA}$ & NLC \\
\hline Ti Gr-12 & 10.98 & $-321(-80)$ & NA & NA & NLC \\
\hline Alloy 400 & 10.97 & $-133(+108)$ & NA & NA & DPA \\
\hline CDA 715 & 10.97 & $-145(+96)$ & NA & NA & DPA \\
\hline
\end{tabular}

$* 52.6 \mathrm{~g} / \mathrm{L}$ of NaCl $+0.074 \mathrm{~g} / \mathrm{L}$ of $\mathrm{Ca}(\mathrm{OH})_{2}$

Table 5

Results of CPP Tests at $60^{\circ} \mathrm{C}$ in Neutral Salt Solution**

Material Tested

$\mathrm{pH} \quad \underline{\mathrm{E}}_{\mathrm{cor}}(\mathrm{mV})$

$\underline{E}_{\text {pit }}(\mathrm{mV})$

$\underline{E}_{\text {prot }}(\mathrm{mV})$

Observation

Type 304 SS

SCE (SHE) SCE (SHE)

Type 316L SS

$6.01-188(+53) \quad-33(+208)$

NA

NRP

Alloy 825

$5.72-172(+69)$

$-95(+146)$

NA

NRP

Alloy G-3

$\begin{array}{llll}6.24 & -94 & (+147) \quad \text { NA }\end{array}$

NA

NLC

Alloy C-4

$6.23-104(+137) \quad$ NA

NA

NLC

Alloy C-22

$6.50-260(-19)$

NA

NA

NLC

Ti Gr-12

$6.50-172(+69)$

NA

NA

NLC

Alloy 400

$6.41-256(-15)$

NA

NLC

CDA 715

$\begin{array}{lll}6.50 & -256(-15) \quad N A\end{array}$

NA

DPA

$6.44-72(+169) \quad$ NA

NA

DPA

$* * 52.6 \mathrm{~g} / \mathrm{L}$ of $\mathrm{NaCl}$

Key to Abbreviation:

NRP : Did not exhibit repassivation in the CPP diagram. Showed severe pitting.

NLC: No localized corrosion was observed. The maximum current density was very low. The specimen looked shiny throughout the test.

DPA: The specimen underwent severe dissolution. Alloying element, possibly nickel, might have dissolved preferentially.

NA : Not available from the CPP diagram.

SCE : Saturated Calomel Electrode

SHE : Standard Hydrogen Electrode 
Table 6

Results of CPP Tests at $60^{\circ} \mathrm{C}$ in Acidic Salt Solution*

\begin{tabular}{|c|c|c|c|c|c|}
\hline Material Tested & $\mathrm{pH}$ & $\underline{\mathrm{E}}_{\mathrm{SCE}} \frac{(\mathrm{mV})}{(\mathrm{SHE})}$ & $\frac{\underline{E}_{\mathrm{pit}}(\mathrm{mV})}{\mathrm{SCE}}$ & $\underline{E}_{\text {prot }}(\mathrm{mV})$ & Observation \\
\hline Type 304 SS & 2.47 & $-321(-80)$ & $-245(-4)$ & NA & NRP \\
\hline Type $316 \mathrm{~L}$ SS & 2.60 & $-238(+3)$ & $-70(+171)$ & NA & NRP \\
\hline Alloy 825 & 2.44 & $+3(+244)$ & NA & NA & NLC \\
\hline Alloy G-3 & 2.49 & $-82(+159)$ & NA & NA & NLC \\
\hline Alloy C-4 & 2.42 & $-84(+157)$ & NA & NA & NLC \\
\hline Alloy C-22 & 2.44 & $-71(+170)$ & NA & NA & NLC \\
\hline Ti Gr-12 & 2.47 & $-221(+20)$ & NA & NA & NLC \\
\hline Alloy 400 & 2.45 & $-235(+6)$ & NA & NA & DPA \\
\hline CDA 715 & 2.44 & $-259(-18)$ & NA & NA & DPA \\
\hline
\end{tabular}

$* 52.6 \mathrm{~g} / \mathrm{L}$ of $\mathrm{NaCl}+0.055 \mathrm{~mL} / \mathrm{L}$ of $\mathrm{H}_{2} \mathrm{SO}_{4}$

\section{Table 7}

Results of CPP Tests at $60^{\circ} \mathrm{C}$ in Alkaline Salt Solution**

\begin{tabular}{|c|c|c|c|c|c|}
\hline Material Tested & $\underline{\mathrm{pH}}$ & $\frac{\mathrm{E}_{\mathrm{cor}}}{\mathrm{SCE}} \frac{(\mathrm{mV})}{\text { (SHE) }}$ & $\frac{\underline{E}_{\mathrm{piti}}(\mathrm{mV})}{\mathrm{SCE}}$ & $\underline{E}_{\text {prot }}(\mathrm{mV})$ & Observation \\
\hline Type 304 SS & 10.79 & $-239(+2)$ & $+85(+326)$ & NA & NRP \\
\hline Type 316L SS & 10.88 & $-137(+104)$ & $-59(+182)$ & NA & NRP \\
\hline Alloy 825 & 10.89 & $-205(+36)$ & NA & NA & NLC \\
\hline Alloy G-3 & 10.75 & $-221(+20)$ & NA & NA & NLC \\
\hline Alloy C-4 & 10.88 & $-304(-63)$ & NA & NA & NLC \\
\hline Alloy C-22 & 10.92 & $-344(-103)$ & NA & NA & NLC \\
\hline Ti Gr-12 & 10.87 & $-388(-147)$ & NA & NA & NLC \\
\hline Alloy 400 & 10.94 & $-110(+131)$ & NA & NA & DPA \\
\hline CDA 715 & 10.86 & $-136(+105)$ & NA & NA & DPA \\
\hline
\end{tabular}

$* * 52.6 \mathrm{~g} / \mathrm{L}$ of $\mathrm{NaCl}+0.074 \mathrm{~g} / \mathrm{L}$ of $\mathrm{Ca}(\mathrm{OH})_{2}$

Key to Abbreviation:

NRP: Did not exhibit repassivation in the CPP diagram. Showed severe pitting.

NLC: No localized corrosion was observed. The maximum current density was very low. The specimen looked shiny throughout the test.

DPA : The specimen underwent severe dissolution. Alloying element, possibly nickel, might have dissolved preferentially.

NA : Not available from the CPP diagram.

SCE : Saturated Calomel electrode

SHE : Standard Hydrogen Electrode 
Table 8

Results of CPP Tests at $90^{\circ} \mathrm{C}$ in Neutral Salt Solution*

\begin{tabular}{|c|c|c|c|c|c|}
\hline Material Tested & $\mathrm{pH}$ & $\mathrm{E}_{\mathrm{cor}}(\mathrm{mV})$ & $E_{p i t}(m V)$ & $\mathrm{E}_{\mathrm{prot}}(\mathrm{mV})$ & Observation \\
\hline Type 304 SS & 6.39 & $\begin{array}{l}\mathrm{Ag} / \mathrm{AgCl}(\mathrm{SHE}) \\
-144(+78)\end{array}$ & $-100(+122)$ & $\begin{array}{l}\text { Ag/Ag } \\
\text { NA }\end{array}$ & NRP \\
\hline Type 316L SS & 6.42 & $-162(+60)$ & $+10(+232)$ & NA & NRP \\
\hline Alloy 825 & 6.60 & $-84(+138)$ & $+140(+362)$ & $+25(+247)$ & FDP \\
\hline Alloy G-3 & 6.64 & $-103(+119)$ & $+165(+387)$ & $+112(+334)$ & NLC \\
\hline Alloy C-4 & 6.86 & $-167(+55)$ & NA & NA & NLC \\
\hline Alloy C-22 & 6.86 & $-137(+85)$ & NA & NA & NLC \\
\hline Ti Gr-12 & 6.62 & $-195(+27)$ & $\mathrm{NA}^{\circ}$ & NA & NLC \\
\hline Alloy 400 & 6.86 & $-234(-12)$ & NA & NA & DPA \\
\hline CDA 715 & 6.62 & $-280(-58)$ & NA & NA & DPA \\
\hline
\end{tabular}

$* 52.6 \mathrm{~g} / \mathrm{L}$ of $\mathrm{NaCl}$

Table 9

Results of CPP Tests at $90^{\circ} \mathrm{C}$ in Acidic Salt Solution**

\begin{tabular}{|c|c|c|c|c|c|}
\hline Material Tested & $\mathrm{pH}$ & $\underline{\mathrm{E}}_{\mathrm{com}}(\mathrm{mV})$ & $\frac{\mathrm{E}_{\mathrm{pit}}(\mathrm{mV})}{\mathrm{m}_{\mathrm{N}}}$ & ${\underline{E_{\text {prot }}}}_{(\mathrm{mV})}$ & Observation \\
\hline Type 304 SS & 2.35 & $\begin{array}{l}\mathrm{Ag} / \mathrm{AgCl}(\mathrm{SHE}) \\
-285(-63)\end{array}$ & $\begin{array}{l}\text { AgAgC (SHE) } \\
-160(+62)\end{array}$ & $\begin{array}{l}\text { AgAgCl (SHE) } \\
\text { NA }\end{array}$ & NRP \\
\hline Type 316L SS & 2.35 & $-211(+11)$ & $-85(+137)$ & NA & NRP \\
\hline Alloy 825 & 2.36 & $-174(+48)$ & $+130(+352)$ & $+45(+267)$ & PAC \\
\hline Alloy G-3 & 2.36 & $-9(+213)$ & NA & NA & PD \\
\hline Same (Repeat) & 2.50 & $-119(+103)$ & NA & NA & PD \\
\hline Alloy C -4 & 2.38 & $-10(+212)$ & NA & NA & NLC \\
\hline Alloy C-22 & 2.40 & $-46(+176)$ & NA & NA & NLC \\
\hline Ti Gr-12 & 2.37 & $-158(+64)$ & NA & NA & NLC \\
\hline Alloy 400 & 2.37 & $-298(-76)$ & NA & NA & DPA \\
\hline CDA 715 & 2.37 & $-285(-63)$ & NA & NA & DPA \\
\hline
\end{tabular}

$* * 52.6 \mathrm{~g} / \mathrm{L}$ of $\mathrm{NaCl}+0.055 \mathrm{~mL} / \mathrm{L}$ of $\mathrm{H}_{2} \mathrm{SO}_{4}$

Key to Abbreviation :

NRP: Did not exhibit repassivation in the CPP diagram. Showed severe pitting.

FDP: Showed a few deep pits only. Also, showed repassivation in the CPP diagram.

PAC: Numerous pits were seen around the specimen circumference. Repassivation was observed.

NLC: No localized corrosion was observed. The maximum current density was very low. The specimen looked shiny throughout the test.

PD : The specimen underwent pitting and dissolution. The maximum current density was very high.

DPA : The specimen underwent severe dissolution. Alloying element, possibly nickel, might have dissolved preferentially.

NA: Not available from the CPP diagram.

SHE : Standard Hydrogen Electrode 
Table 10

Results of CPP Tests at $90^{\circ} \mathrm{C}$ in Alkaline Salt Solution*

\begin{tabular}{|c|c|c|c|c|c|}
\hline Material Tested & $\mathrm{pH}$ & $\frac{E_{\text {corm }}(\mathrm{mV})}{\mathrm{Ag} / \mathrm{AgCl}}$ & $\underset{\mathrm{Ag} / \mathrm{AgCl} \text { (SHE) }}{\mathrm{E}_{\mathrm{pit}}(\mathrm{mV})}$ & $\underline{E}_{\text {prot }}(\mathrm{mV})$ & Observation \\
\hline Type 304 SS & 10.85 & $-235(-13)$ & $-15(+207)$ & NA & NRP \\
\hline Type 316L SS & 10.84 & $-200(+22)$ & $-120(+102)$ & NA & NRP \\
\hline Alloy 825 & 10.83 & $-93(+129)$ & NA & NA & NLC \\
\hline Alloy G-3 & 10.83 & $-176(+46)$ & NA & NA & NLC \\
\hline Alloy C-4 & 10.84 & $-278 \quad(-56)$ & NA & NA & NLC \\
\hline Alloy C-22 & 10.84 & $-213(+9)$ & NA & NA & NLC \\
\hline Ti Gr-12 & 10.85 & $-402(-180)$ & NA & NA & NLC \\
\hline Alloy 400 & 10.85 & $-93(+129)$ & NA & NA & DPA \\
\hline CDA 715 & 10.85 & $-114(+108)$ & NA & NA & DPA \\
\hline
\end{tabular}

$* 52.6 \mathrm{~g} / \mathrm{L}$ of NaCl $+0.074 \mathrm{~g} / \mathrm{L}$ of $\mathrm{Ca}(\mathrm{OH})_{2}$

Key to Abbreviation :

NRP: Did not exhibit repassivation in the CPP diagram. Showed severe pitting.

NLC: No localized corrosion was observed. The maximum current density was very low. The specimen looked shinny throughout the test.

DPA : The specimen underwent severe dissolution. Alloying element, possibly nickel, might have dissolved preferentially.

NA: Not available from the CPP diagram.

SHE : Standard Hydrogen Electrode.

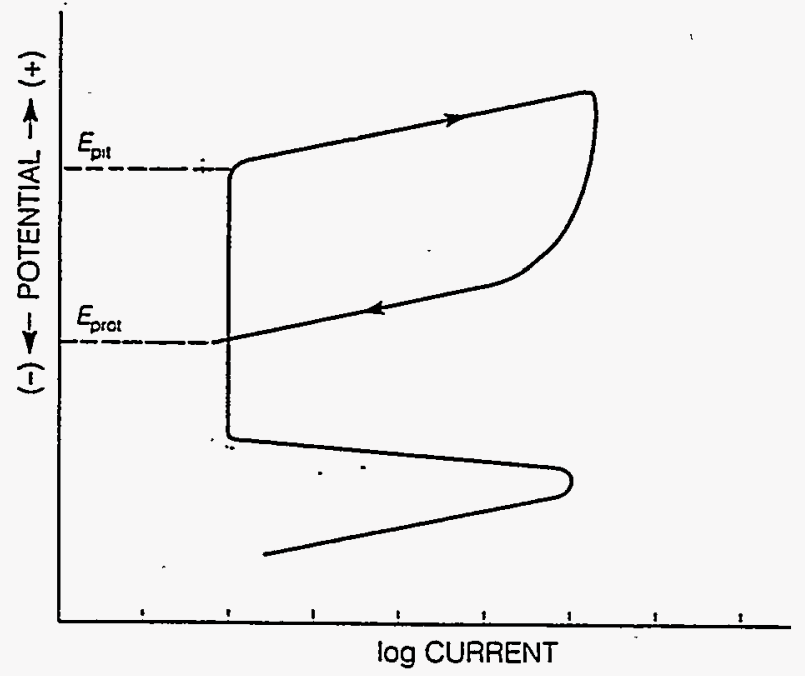

Figure 1. A Schematic View of a CPP Diagram Showing Critical Pitting Potential $\left(E_{\text {pit }}\right)$ and Protection Potential $\left(E_{\text {prot }}\right)$ 


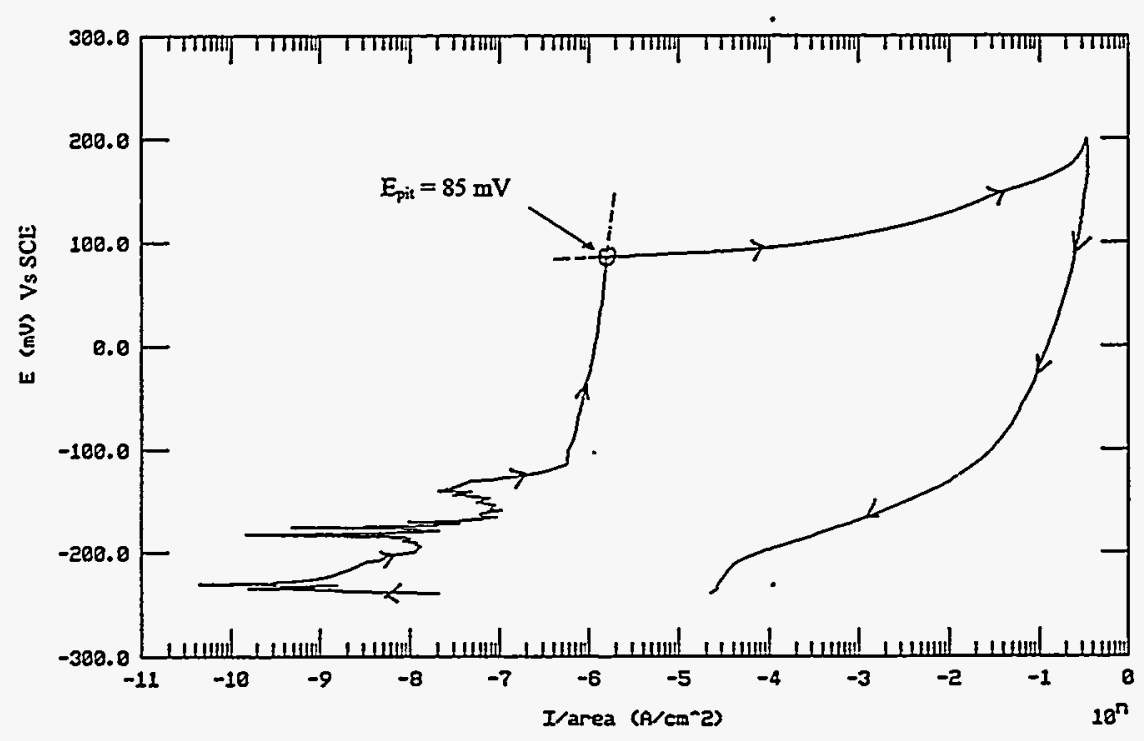

Figure 2. CPP Diagram of Type 304 Stainless Steel in Alkaline Concentrated Brine ( $\mathrm{pH} 10.79)$ at $60^{\circ} \mathrm{C}$

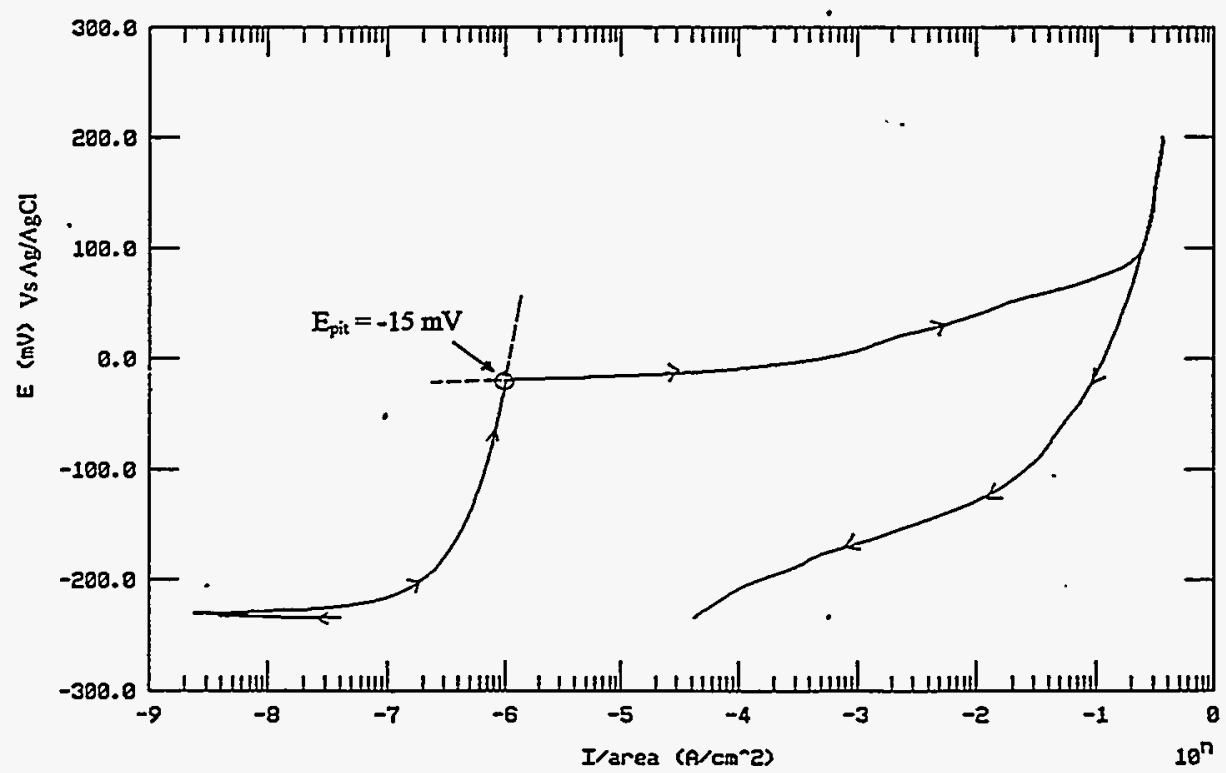

Figure 3. CPP Diagram of Type 304 Stainless Steel in Alkaline Concentrated Brine $(\mathrm{pH} \sim 10.85)$ at $90^{\circ} \mathrm{C}$ 


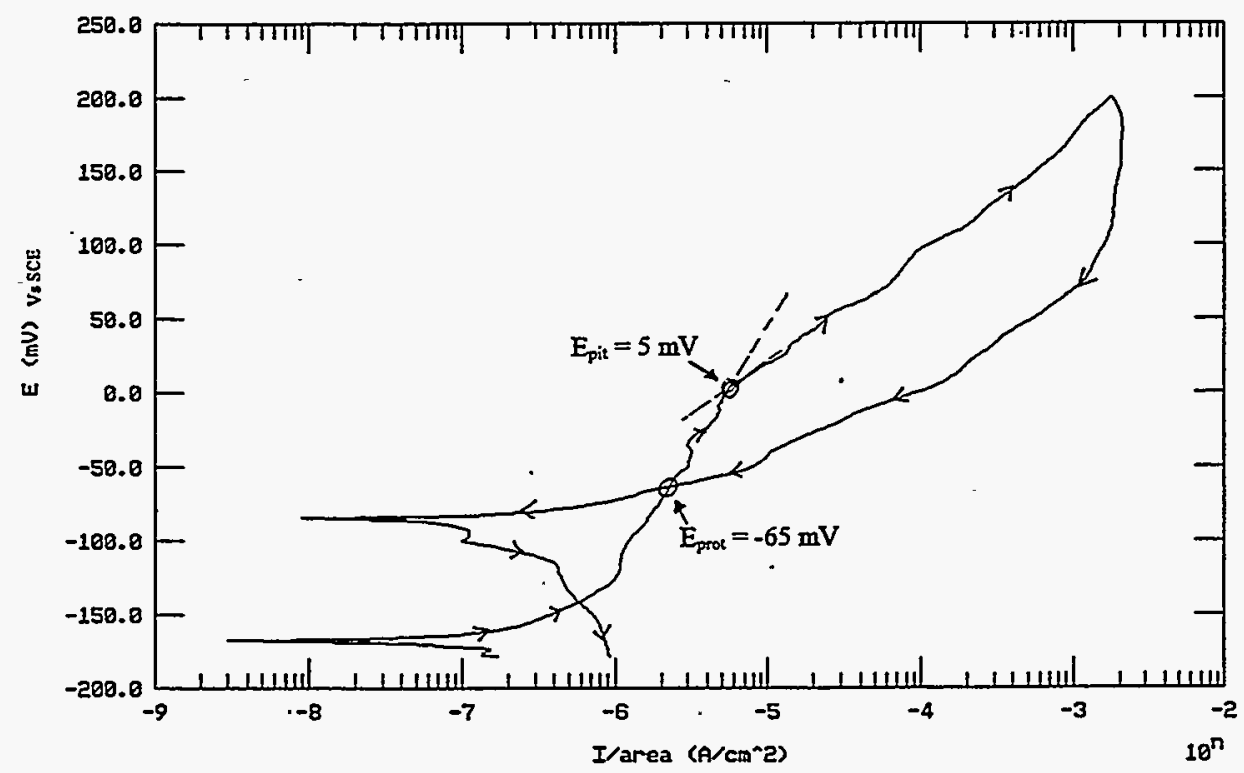

Figure 4. CPP Diagram of Type $316 \mathrm{~L}$ Stainless Steel in Acidified Concentrated Brine ( $\mathrm{pH}$ 2.54) at Ambient Temperature

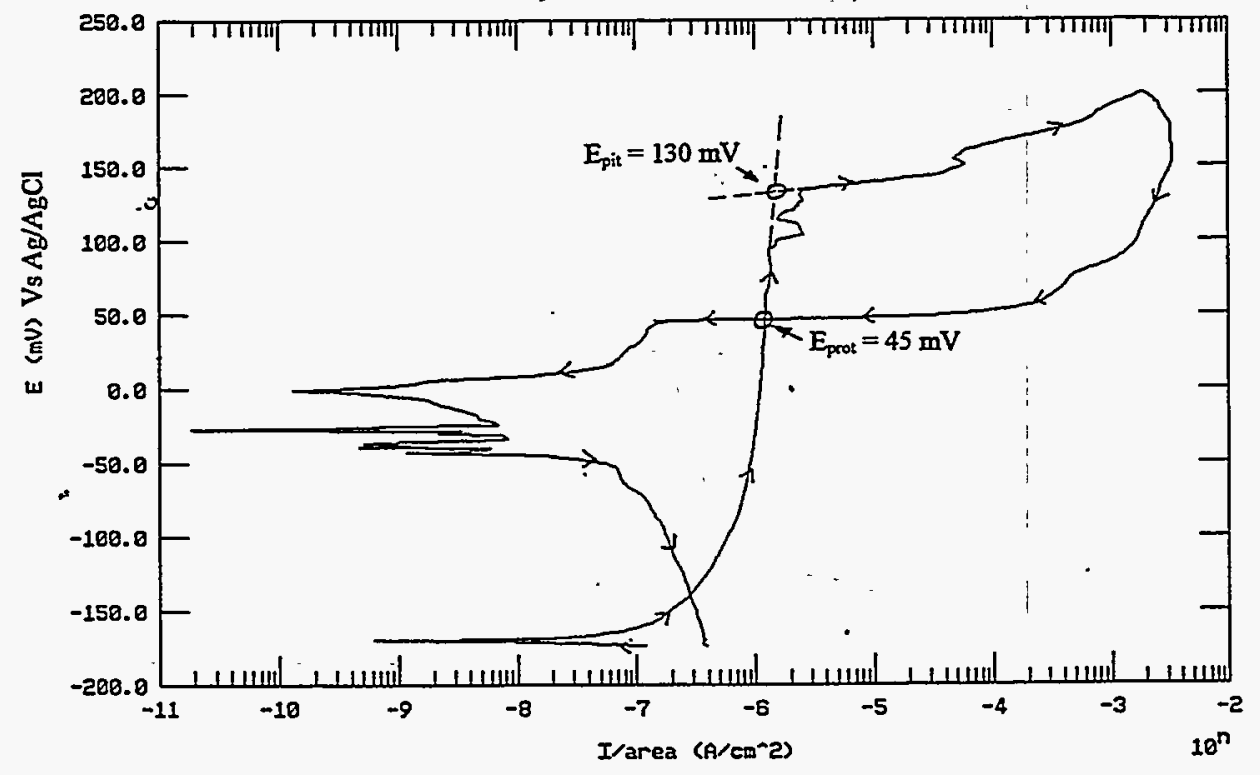

Figure 5. CPP Diagram of Alloy 825 in Acidified Concentrated

Salt Solution (pH 2.36) at $90^{\circ} \mathrm{C}$ 


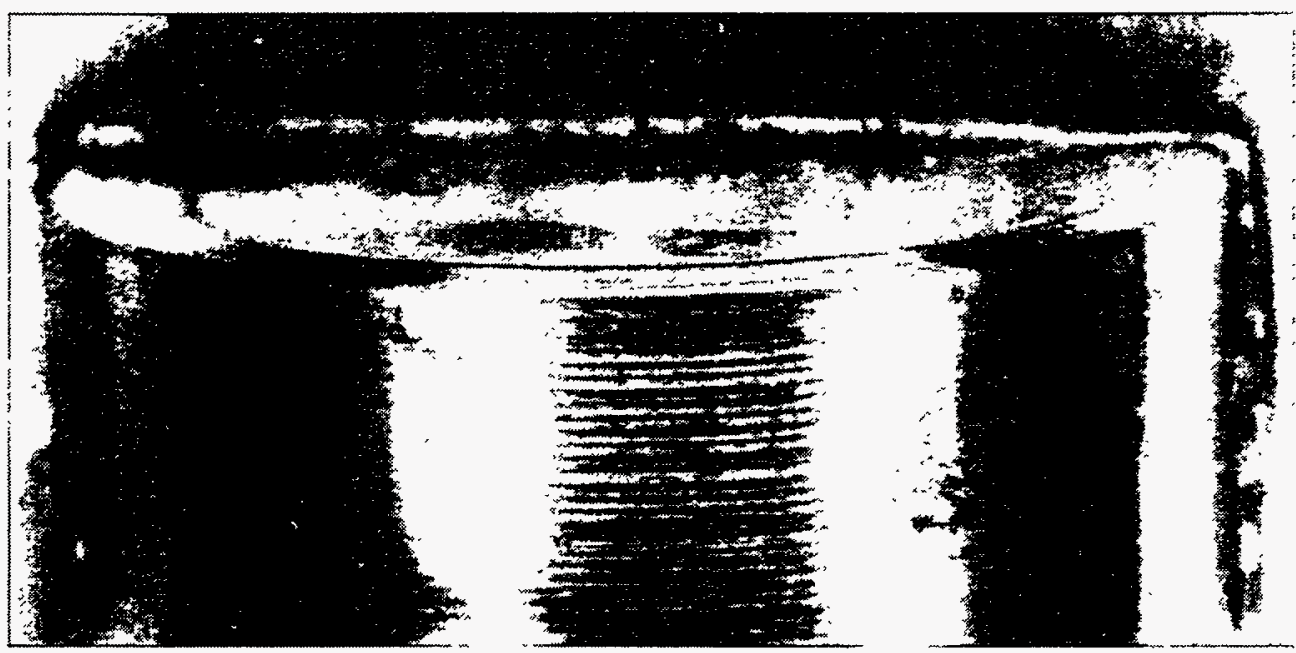

Figure 6. Macroscopic View of Alloy 825 Showing Pits after Exposure in Acidified Concentrated Brine ( $\mathrm{pH} \sim 2.36)$ at $90^{\circ} \mathrm{C}$

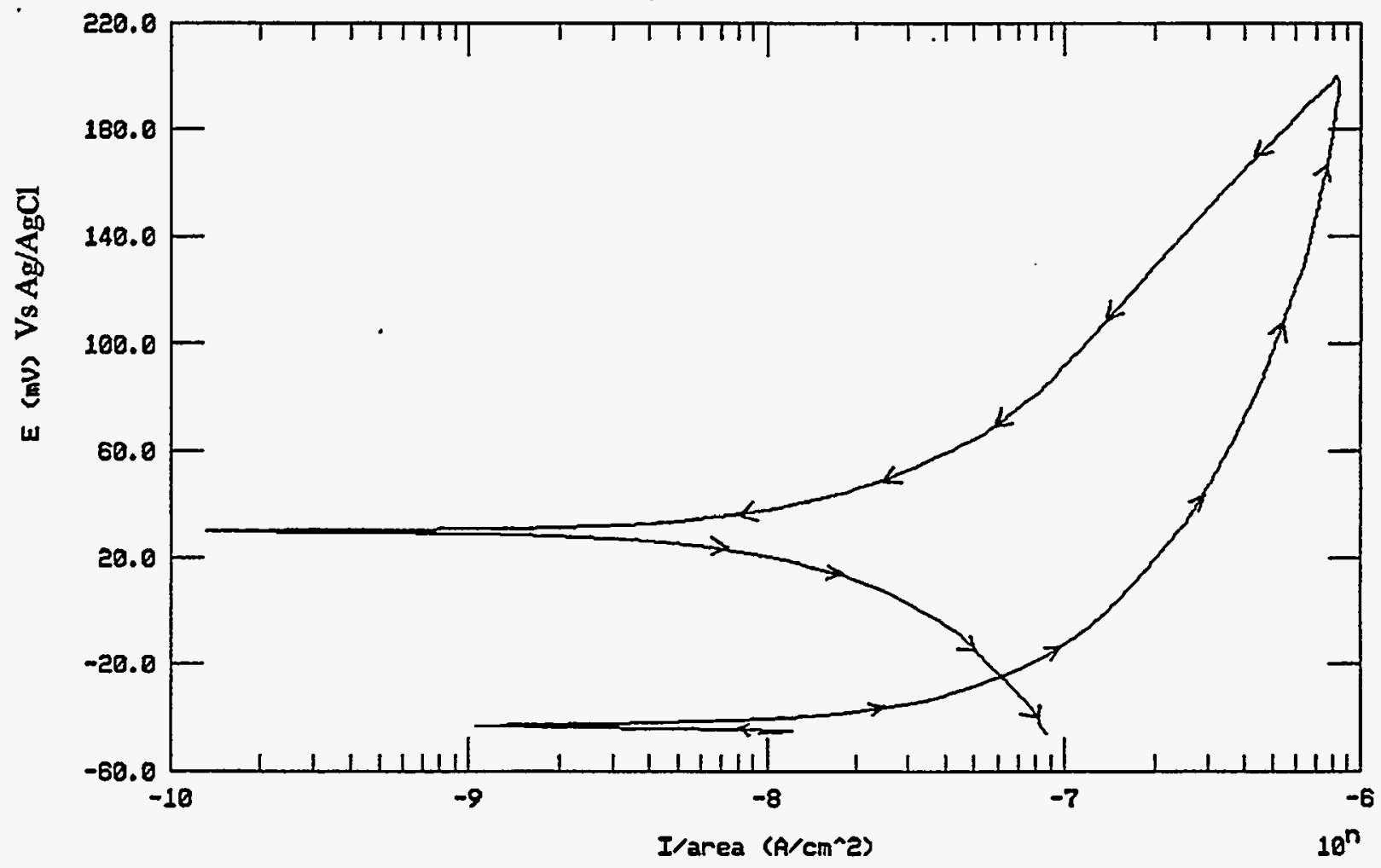

Figure 7. CPP Diagram of Alloy C-22 in Acidified Concentrated Brine ( $\mathrm{pH} 2.40)$ at $90^{\circ} \mathrm{C}$ 


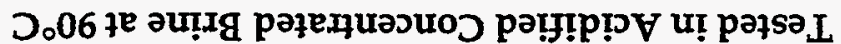

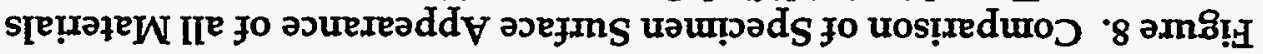

SLL $\forall$ QD

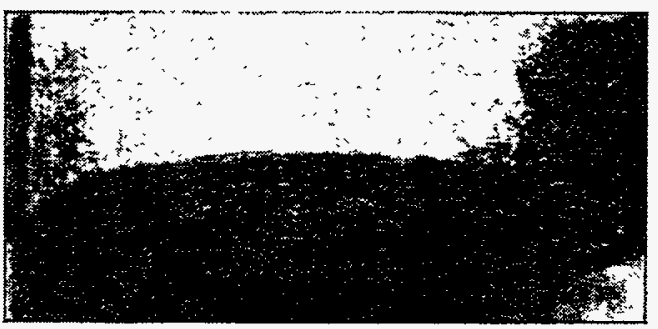

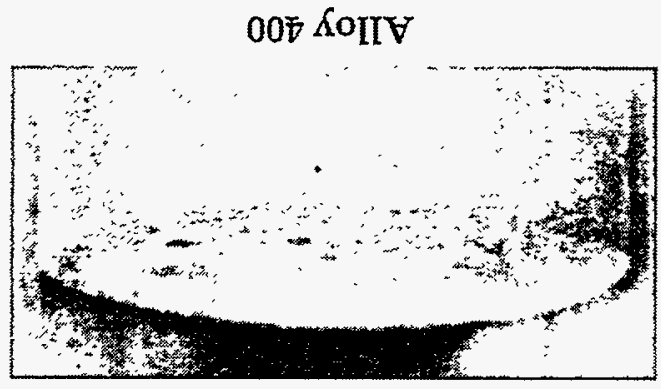

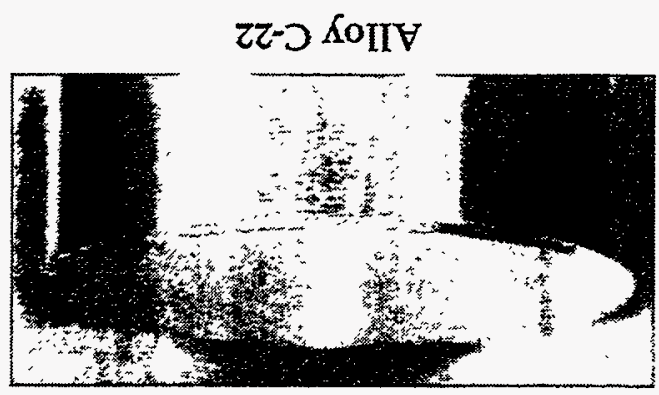

$\varepsilon \rightarrow$ SoIIV

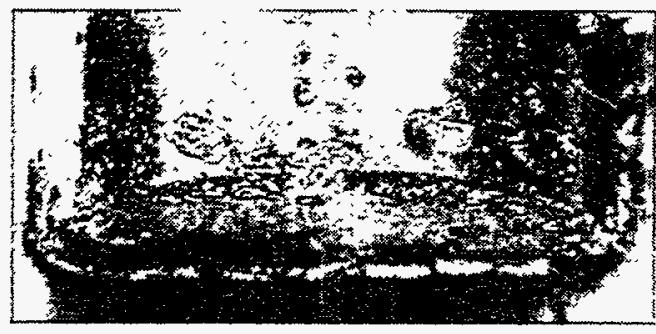

SS T9LE ad $\Lambda_{L}$

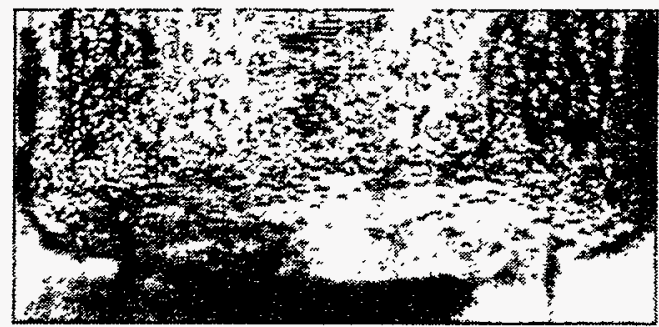

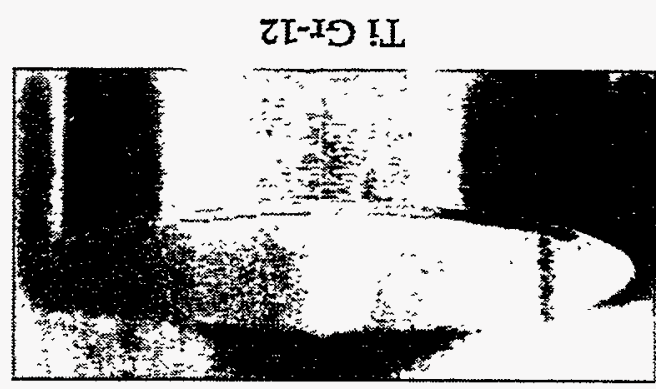
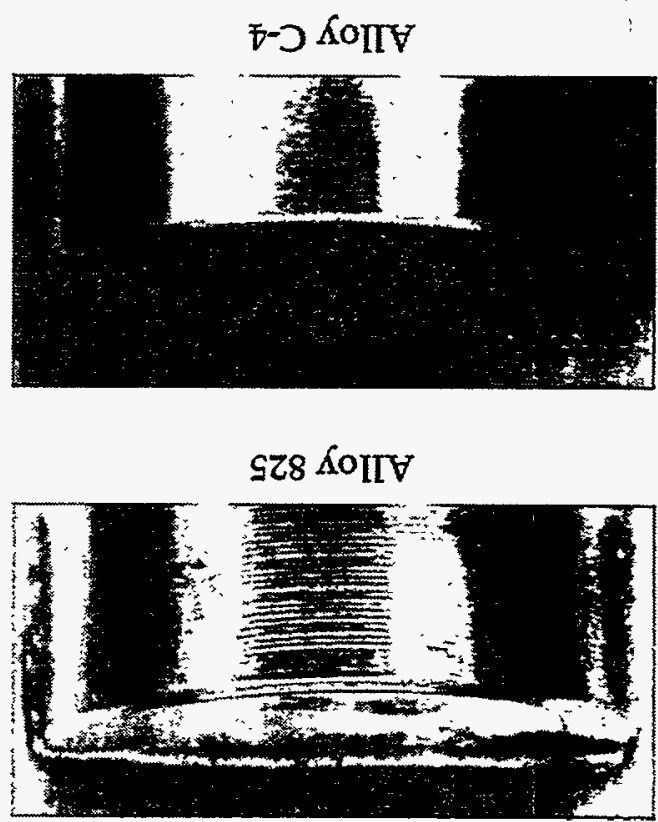

SS $\mathfrak{D} 0 \varepsilon$ $ə \mathrm{~d} \Lambda_{I}$

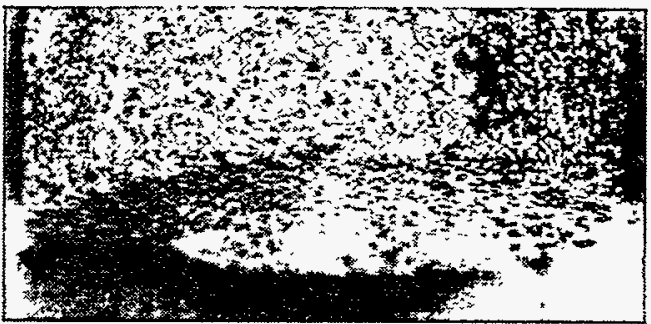




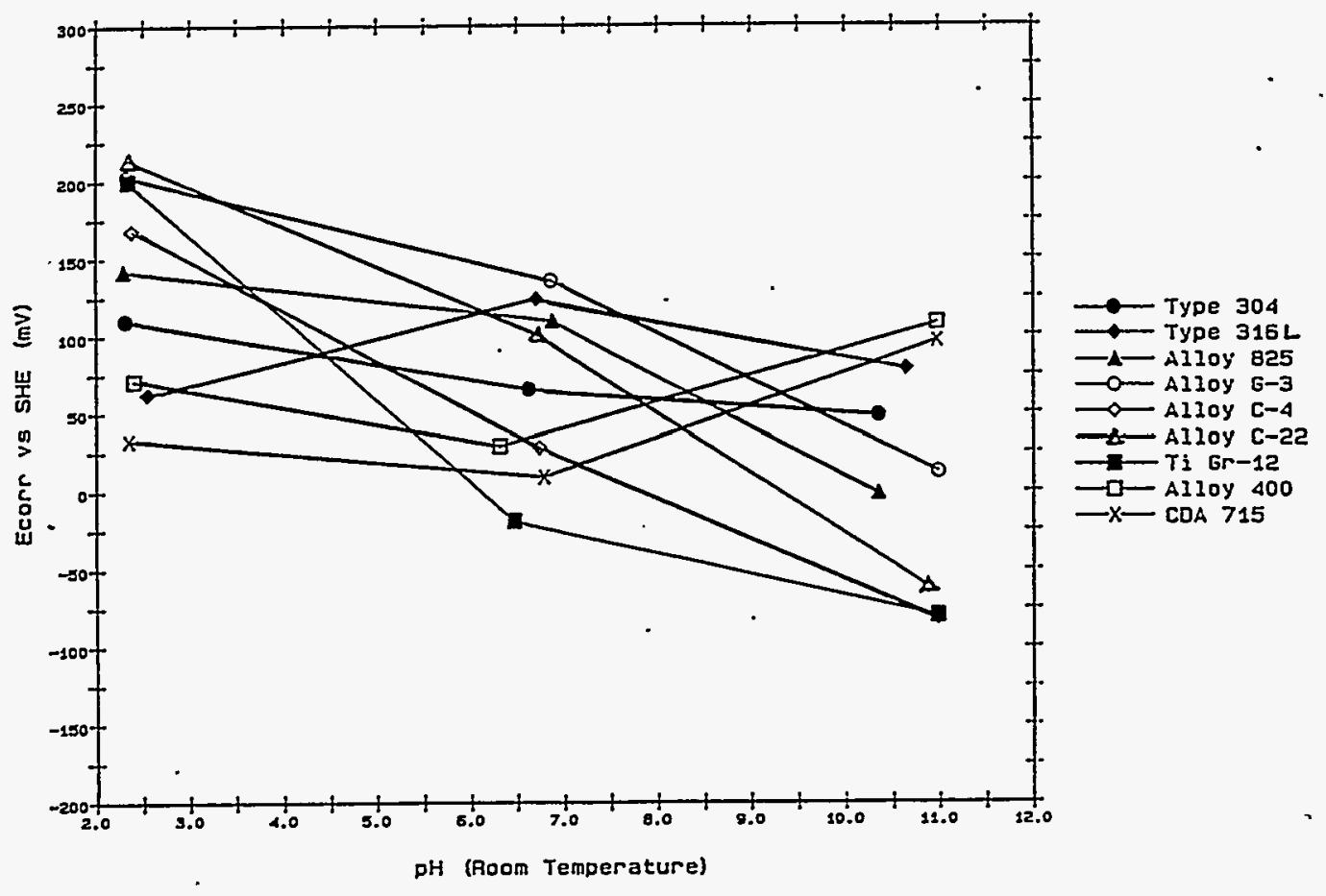

Figure 9. $\mathrm{E}_{\text {corr }}$ Versus $\mathrm{pH}$ at Ambient Temperature

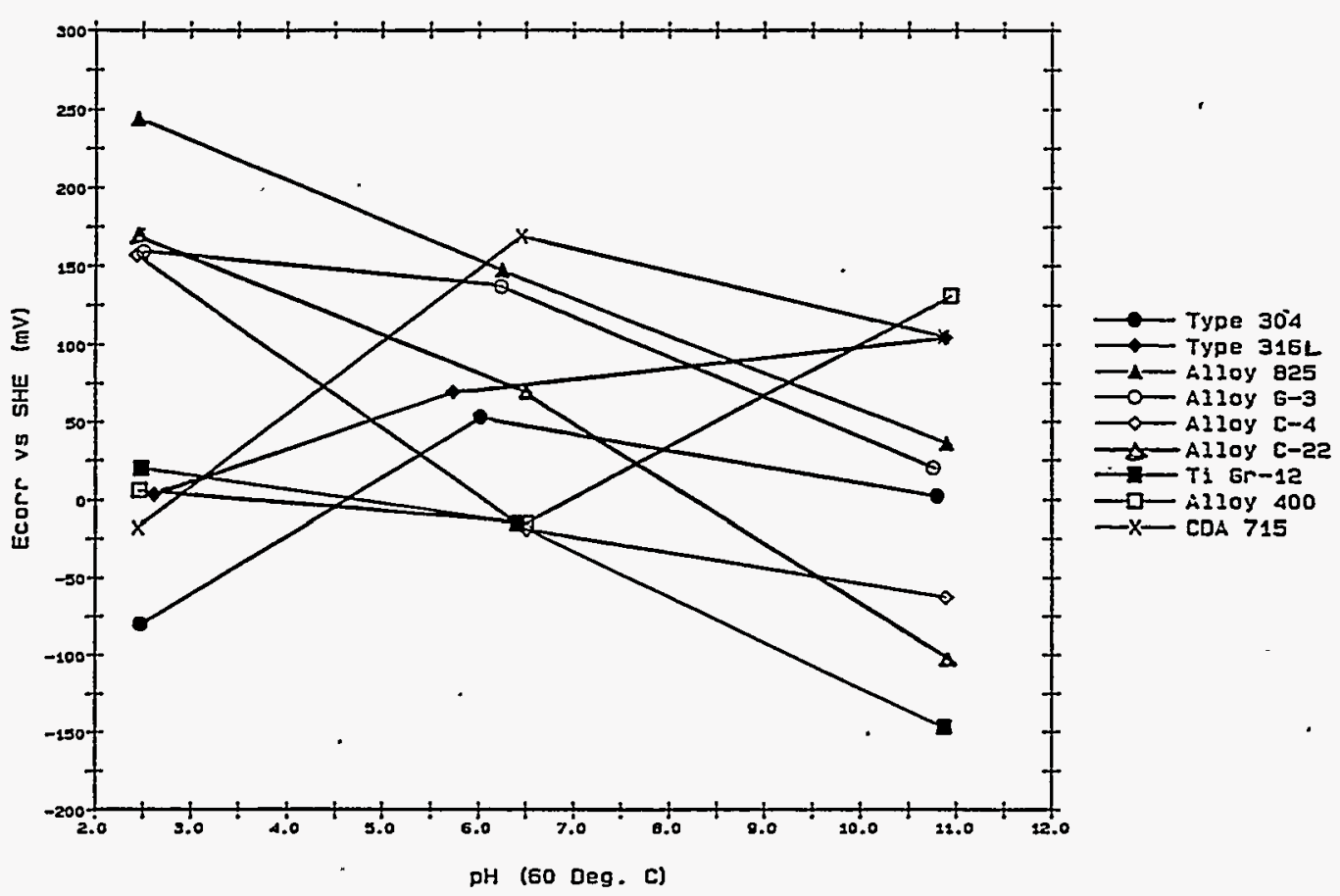

Figure 10. $\mathrm{E}_{\text {corr }}$ Versus $\mathrm{pH}$ at $60^{\circ} \mathrm{C}$ 


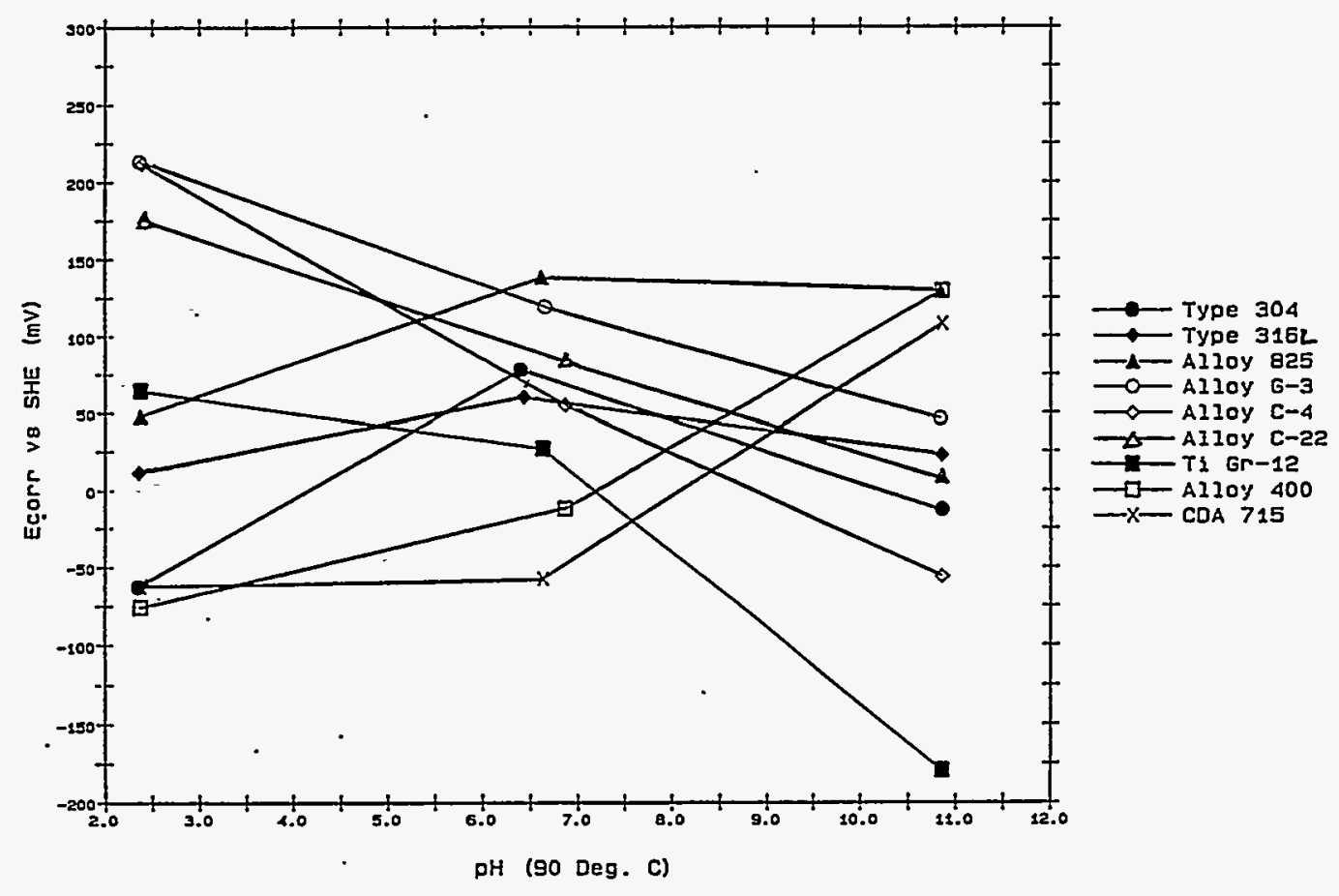

Figure 11. $\mathrm{E}_{\text {corr }}$ Versus $\mathrm{pH}$ at $90^{\circ} \mathrm{C}$

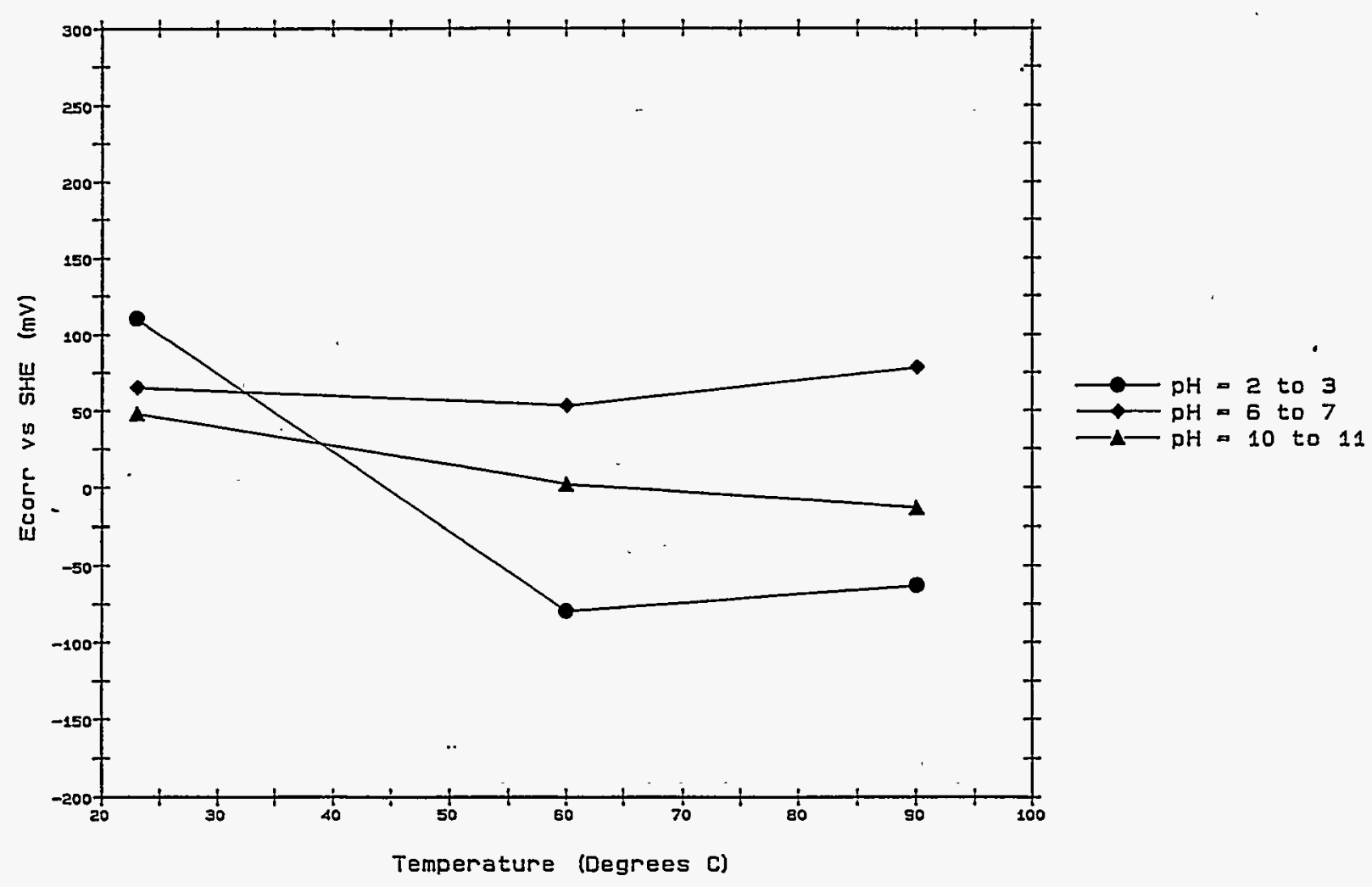

Figure 12. $\mathrm{E}_{\text {corr }}$ Versus Temperature for Type 304 Stainless

Steel for three values of $\mathrm{pH}$ 


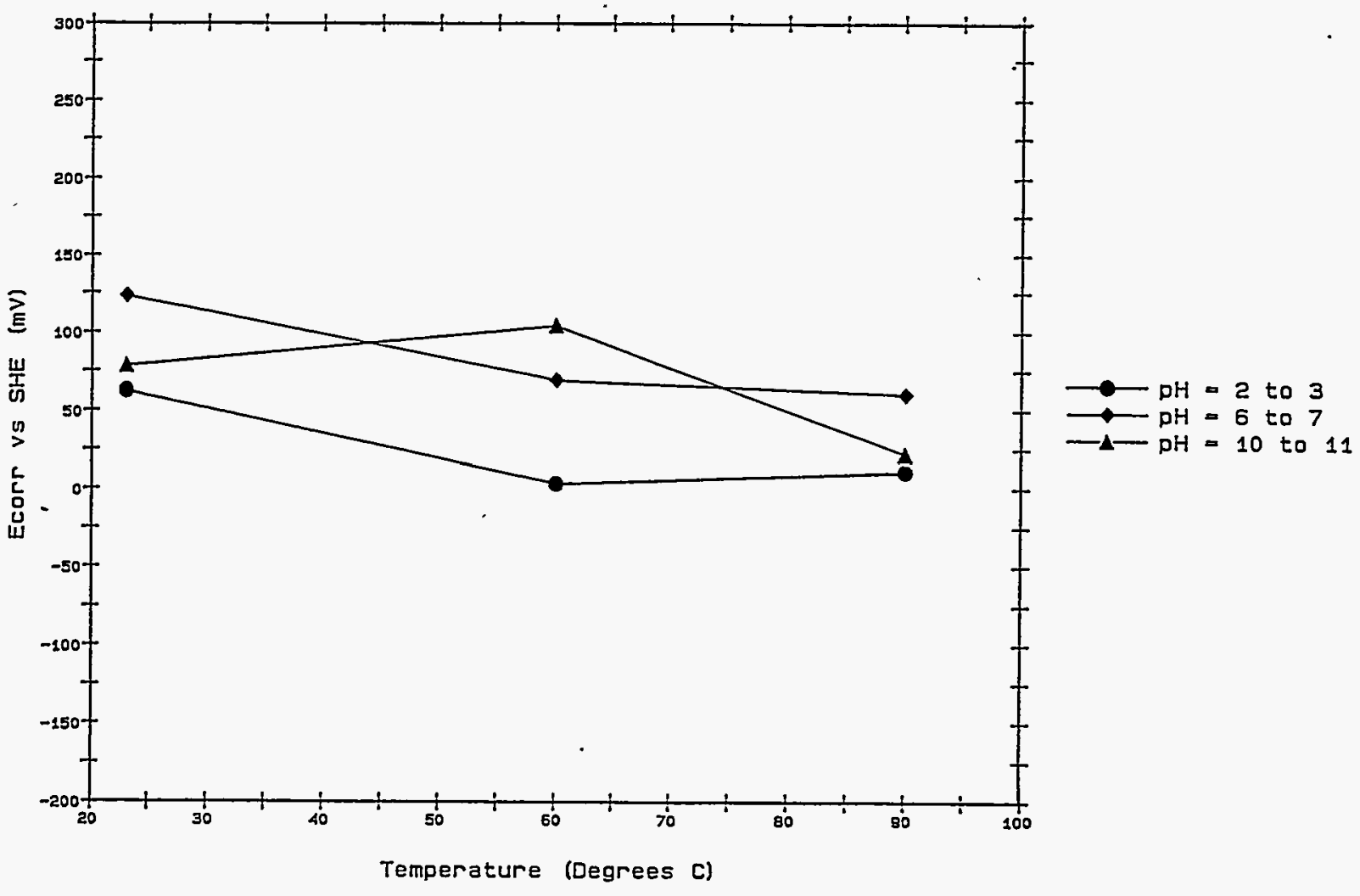

Figure 13. $E_{\text {corr }}$ Versus Temperature for Type 316 , Stainless Steel for three values of $\mathrm{pH}$

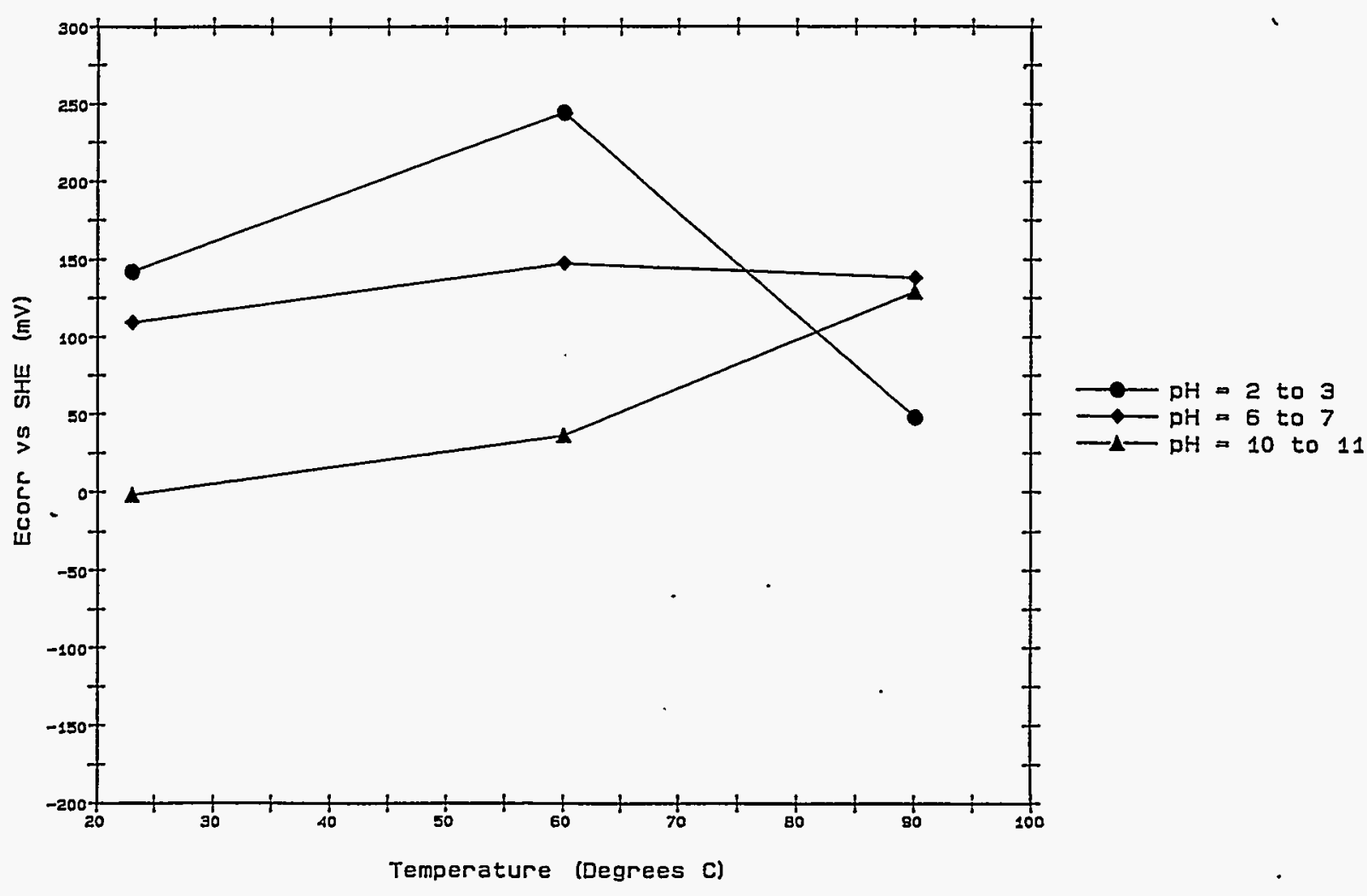

Figure 14. $\mathrm{E}_{\text {corr }}$ Versus Temperature for Alloy 825 for three values of $\mathrm{pH}$ 


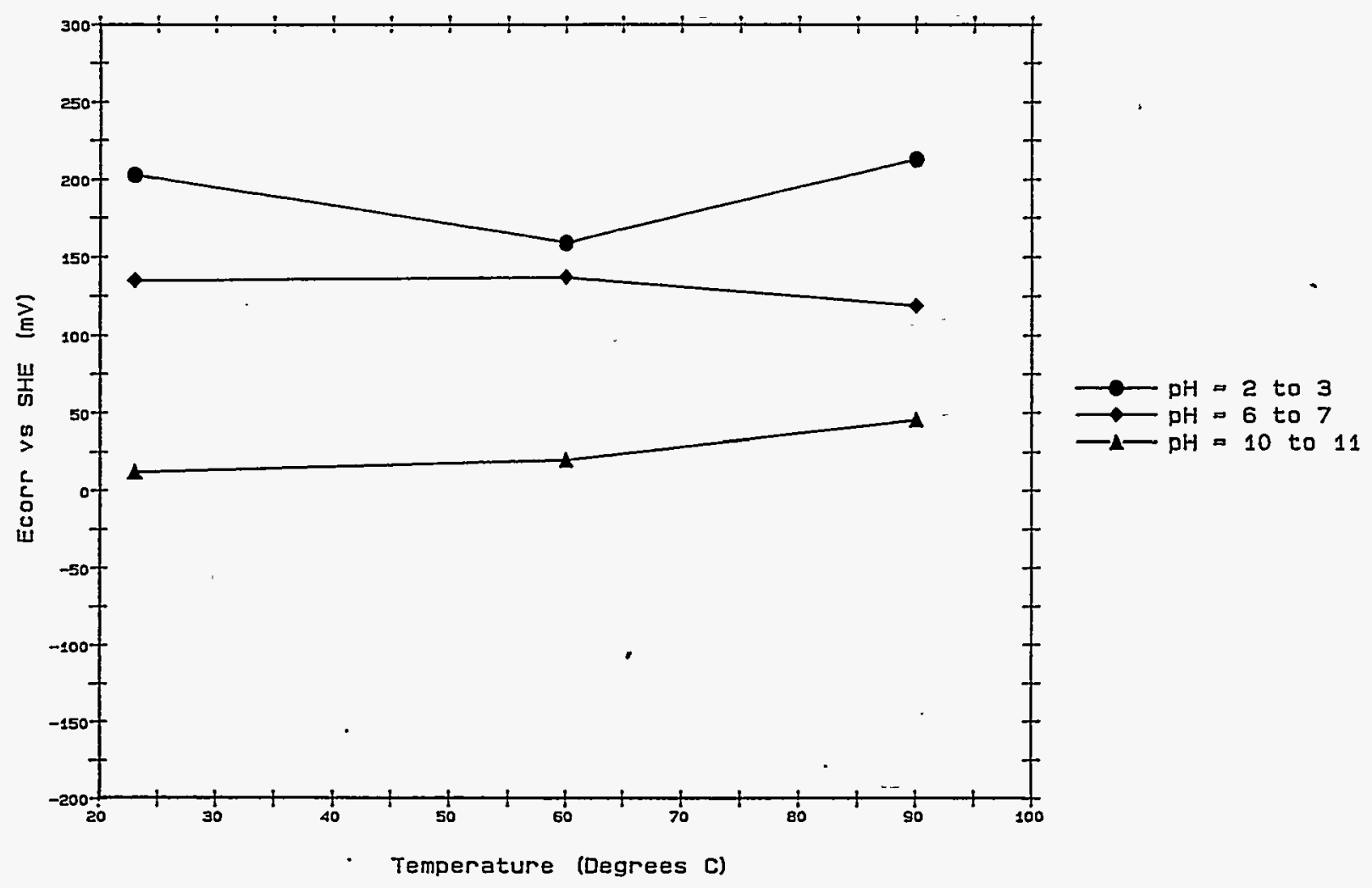

Figure 15. $E_{\text {corr }}$ Versus Temperature for Alloy G-3 for three values of $\mathrm{pH}$

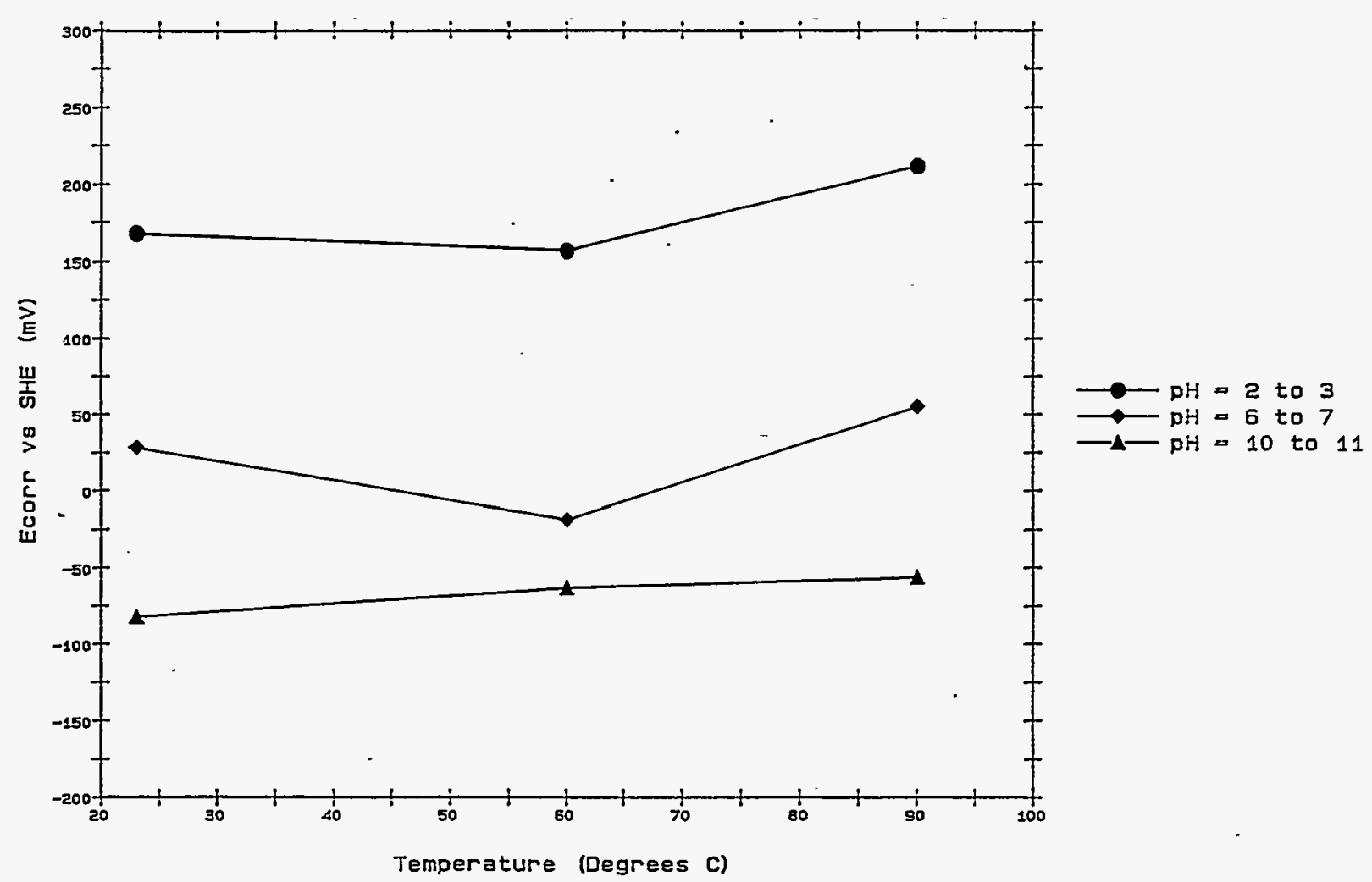

Figure 16. $\mathrm{E}_{\text {corr }}$ Versus Temperature for Alloy $\mathrm{C}-4$ for three values of $\mathrm{pH}$ 


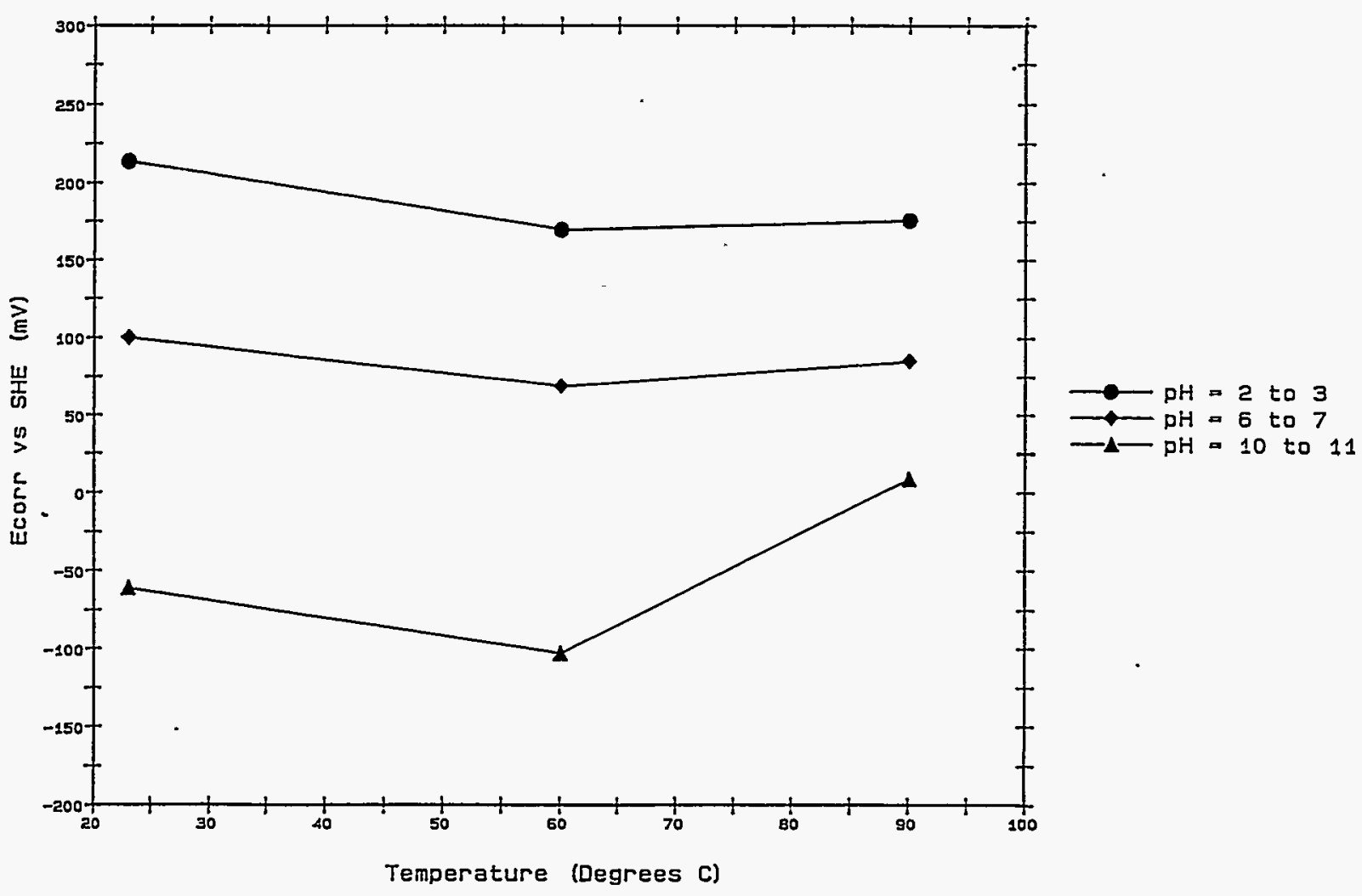

Figure 17. $\mathrm{E}_{\text {cor }}$ Versus Temperature for Alloy C-22 for three values of $\mathrm{pH}$

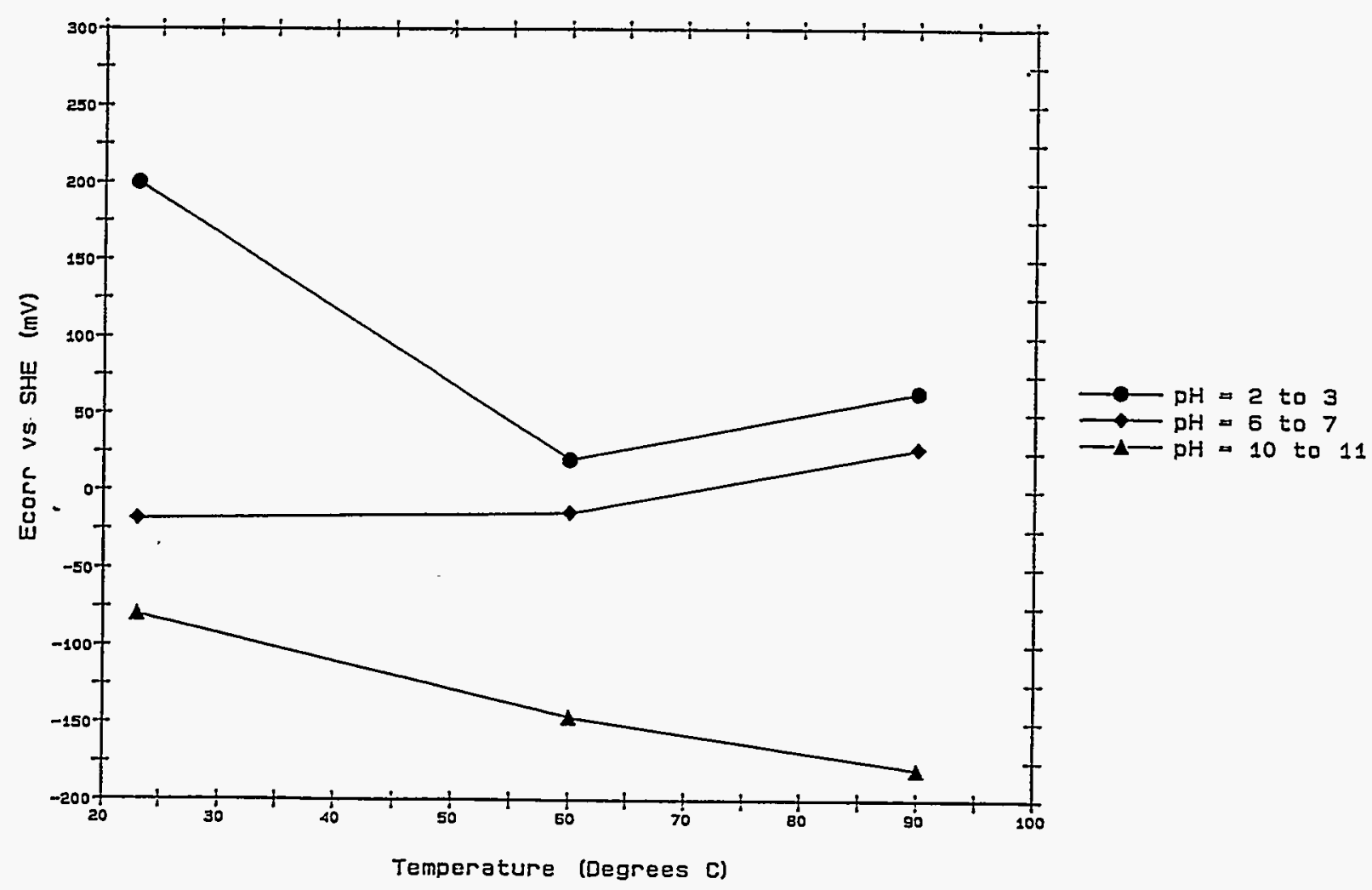

Figure 18. $\mathrm{E}_{\text {corr }}$ Versus Temperature for Ti Gr-12 for three values of $\mathrm{pH}$ 


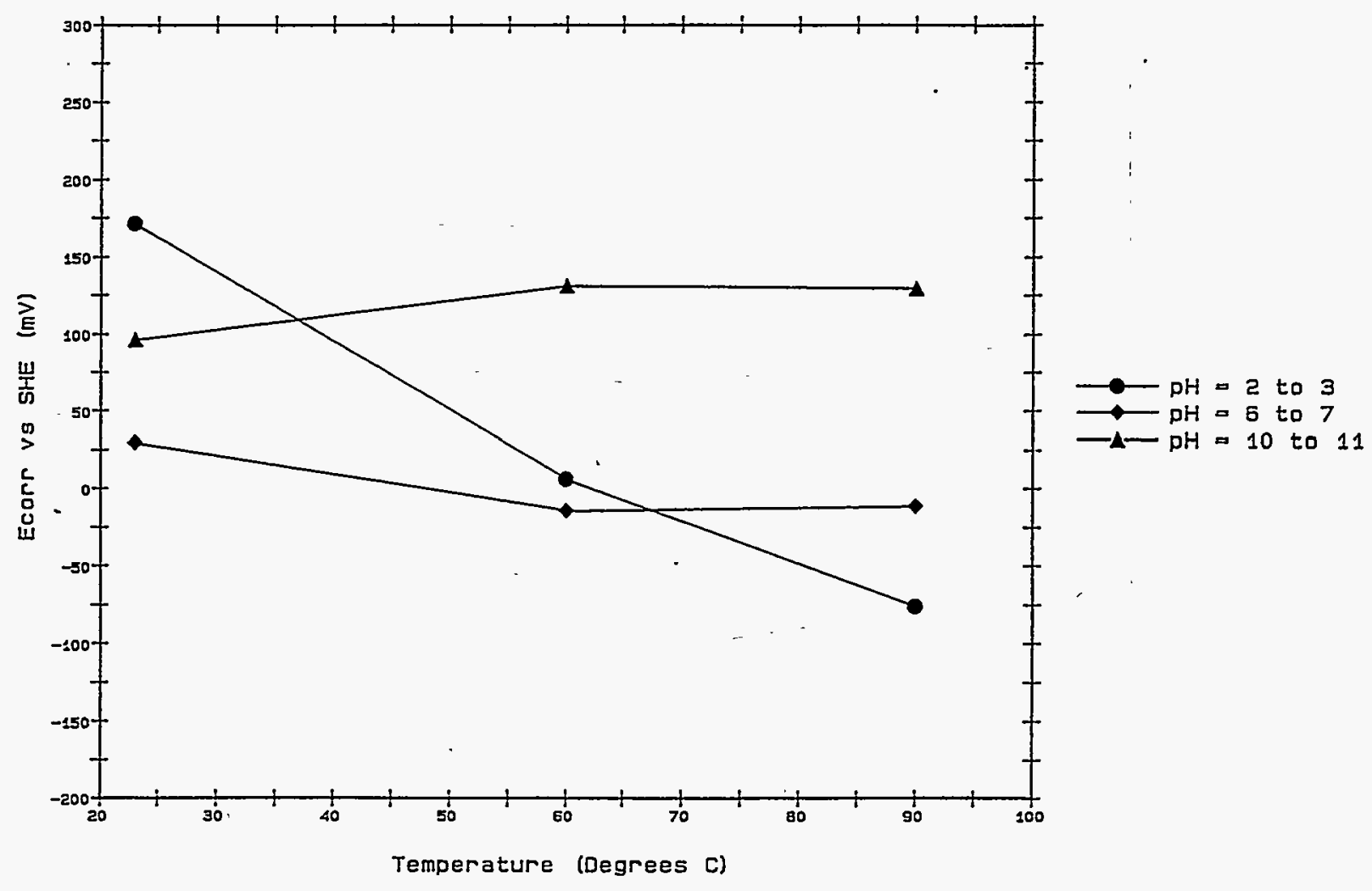

Figure 19. $E_{\text {cor }}$ Versus Temperature for Alloy 400 for three values of $\mathrm{pH}$

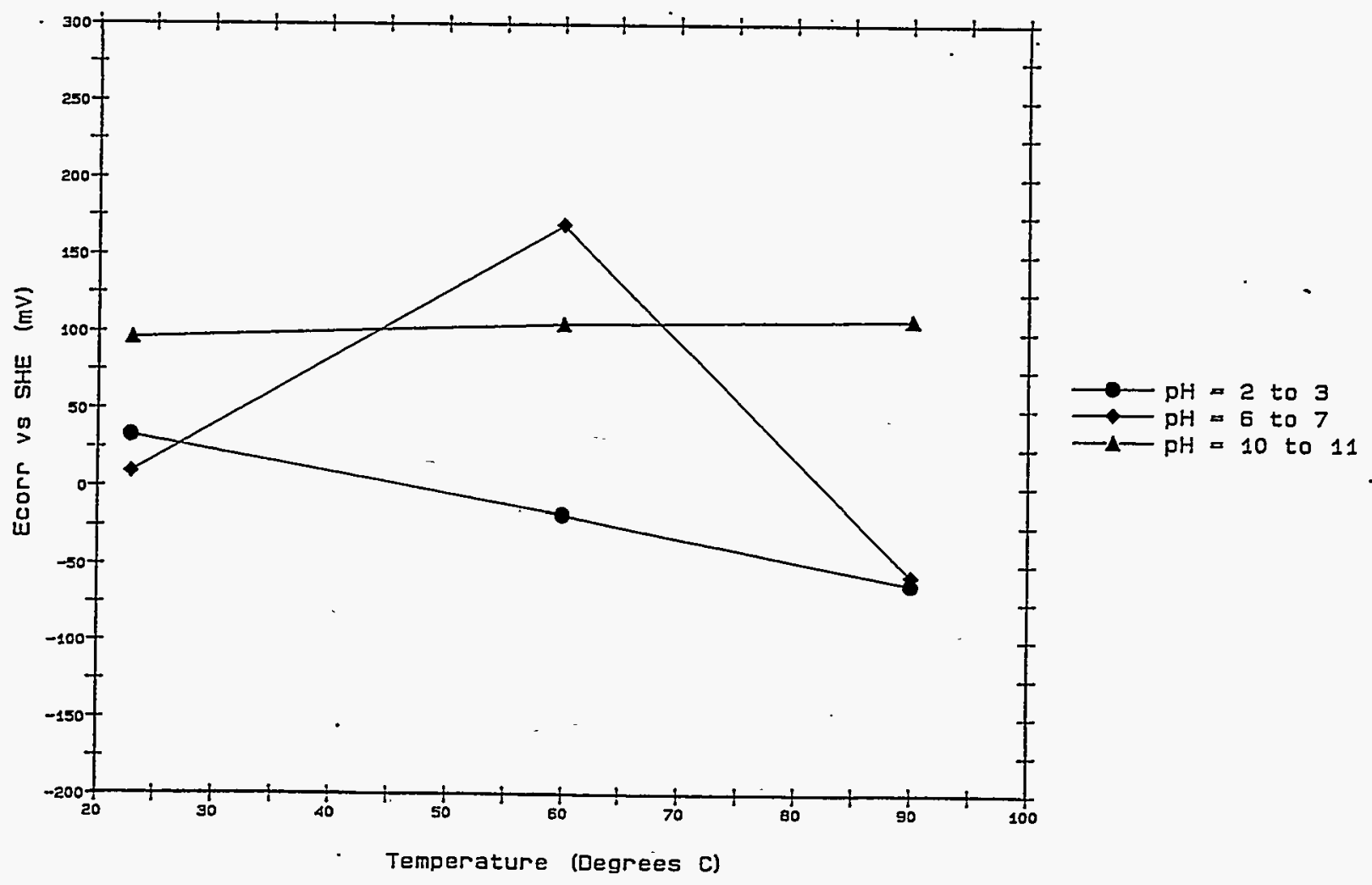

Figure 20. $\mathrm{E}_{\text {cor }}$ Versus Temperature for CDA 715 for three values of $\mathrm{pH}$ 

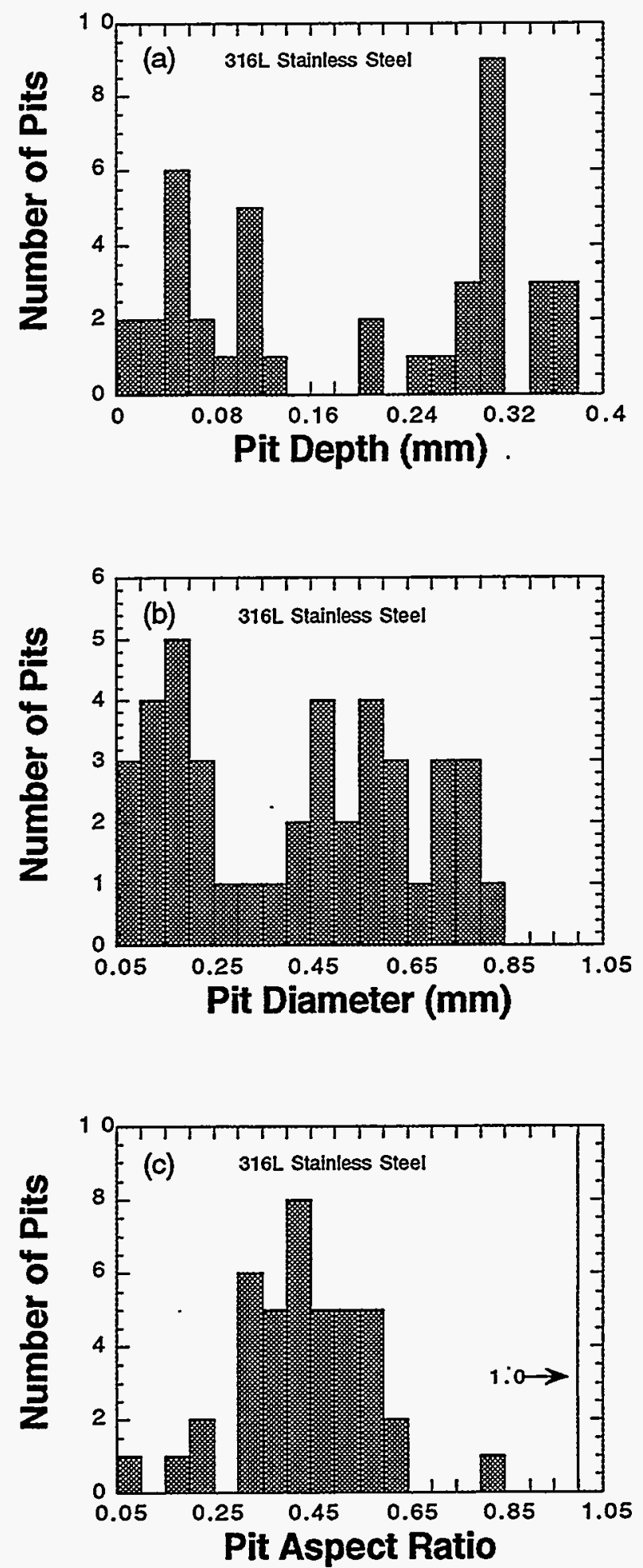

Figure 21. Distributions of (a) pit depth, (b) pit diameter, and (c) pit aspect ratio, resulting from potentiostatic exposure of $316 \mathrm{~L}$ stainless steel for 60 minutes at $60^{\circ} \mathrm{C}$ in neutral $(\mathrm{pH}=6.64), 5 \% \mathrm{NaCl}$ solution at an applied potential of $+281 \mathrm{mV}$ SHE. 

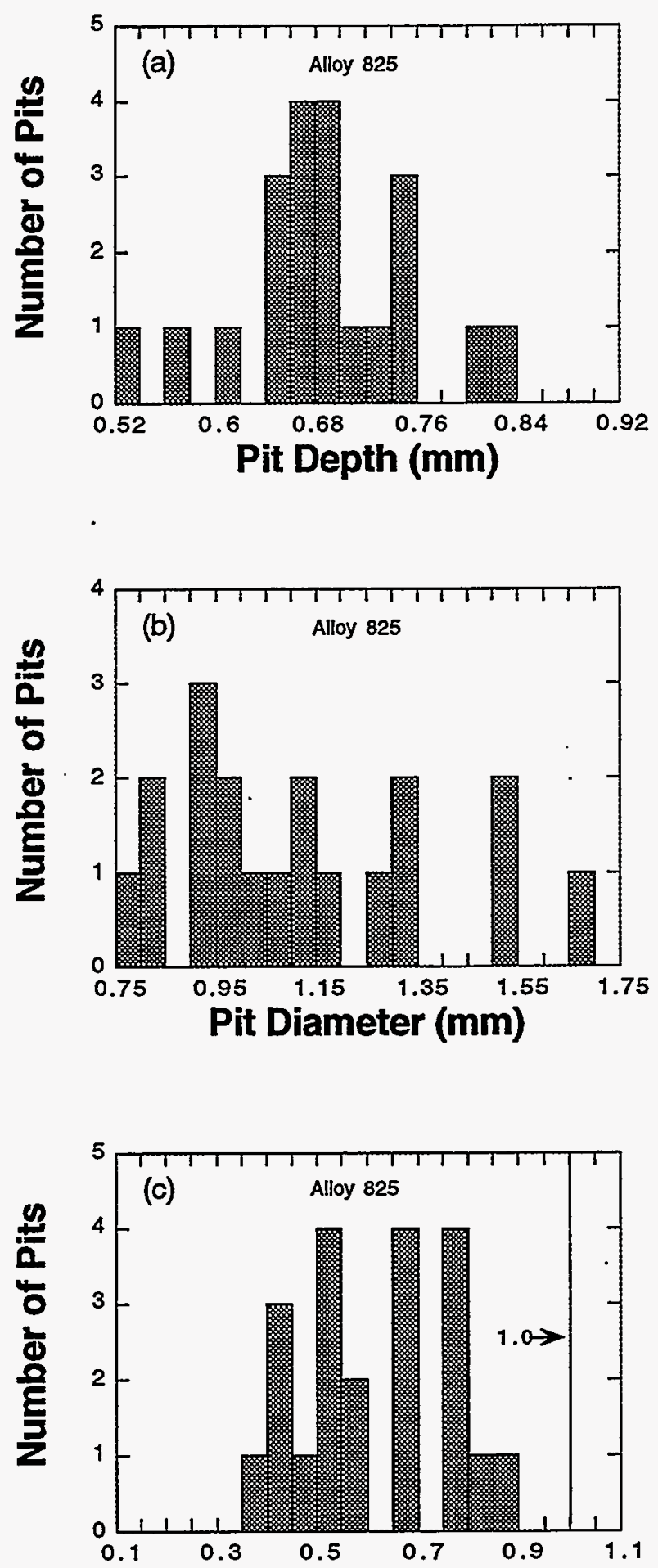

Pit Aspect Ratio

Figure 22. Distributions of (a) pit depth, (b) pit diameter, and (c) pit aspect ratio, resulting from potentiostatic exposure of Alloy 825 for 218 minutes at $90^{\circ} \mathrm{C}$ in acidified $(\mathrm{pH}=2.51), 5 \% \mathrm{NaCl}$ solution at an applied potential of $+392 \mathrm{mV}$ SHE. 

Technical Information Department • Lawrence Livermore National Laboratory

University of California • Livermore, California 94551

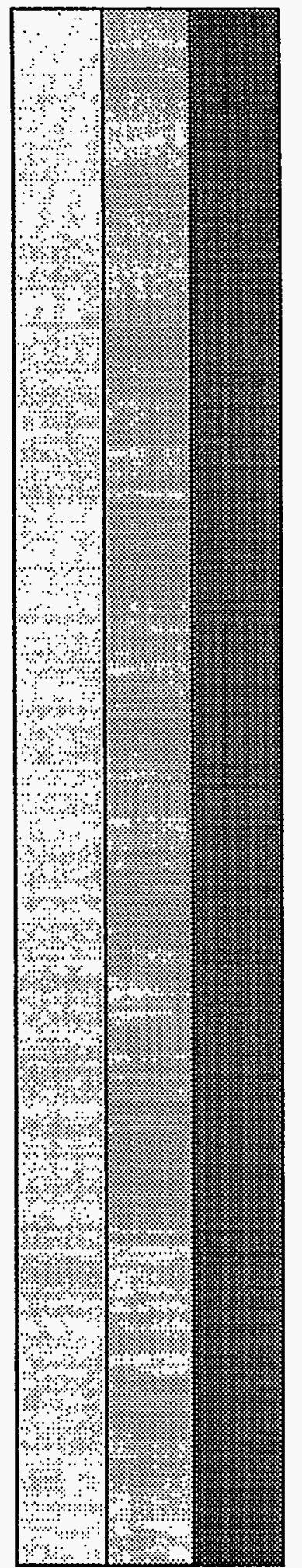

